\title{
Gradišči na Sloki gori in Vinjem hribu nad Vinom na severozahodnem obrobju dolenjske halštatske skupnosti
}

\author{
Gradišče on Sloka gora \\ and Vinji hrib above Vino on the north-western edge \\ of the Dolenjska Hallstatt community
}

\author{
Sneža TECCO HVALA
}

Izvleček

Sondiranje na Sloki gori in Vinjem hribu nad Vinom, ki je bilo opravljeno v letu $1999 \mathrm{v}$ okviru raziskav prazgodovinskih utrjenih naselij na Dolenjskem, osvetljuje severozahodni rob poselitve dolenjske halštatske skupnosti. Gre za manjši višinski naselbini v hribovitem zaledju Ljubljane, na obeh sta bili ugotovljeni dve poselitveni oz. gradbeni fazi, ki ju po sicer skromnih najdbah lahko datiramo v mlajše halštatsko obdobje.

Ključne besede: osrednja Slovenija; starejša železna doba; mlajše halštatsko obdobje; dolenjska halštatska kulturna skupina; naselja

\begin{abstract}
Test excavations on Sloka gora and Vinji hrib above Vino, carried out in 1999 as part of the research of prehistoric fortified settlements in the Dolenjska region, illuminate the north-western edge of the settlement of the Dolenjska Hallstatt community. These are smaller hilltop settlements in the hilly hinterland of Ljubljana, in which two phases have been identified, probably of the Late Hallstatt period according to otherwise modest finds.
\end{abstract}

Keywords: central Slovenia; Early Iron Age; Late Hallstatt period; Dolenjska Hallstatt group; settlements

V okviru raziskav prazgodovinskih utrjenih naselij na Dolenjskem je ekipa Inštituta za arheologijo ZRC SAZU v letu 1999 sondirala na Vinjem hribu nad Vinom in Gradišču na Sloki gori. ${ }^{1}$ Prazgodovinski naselbini na teh dveh vzpetinah omenjajo že viri s konca 19. in prvih desetletij 20. stoletja. ${ }^{2}$ Ležita $\mathrm{v}$ zakotju jugovzhodno od Ljubljane (sl. 1), sredi hribovja med dvema podoljema, po katerih tečeta

1 Janez Dular, Gradišče pod Sloko goro - Sonda 1, Poročilo o sondiranju 31.8.-10.9. 1999; Janez Dular, Vinji hrib nad Vinom - Sonda 1, Poročilo o sondiranju 14.9.-21.9. 1999 (hrani arhiv Inštituta za arheologijo ZRC SAZU).

2 Gl. Puš 1975, 194, 195; Stare 1975, 238. glavni prometni povezavi iz Ljubljanske kotline proti jugu na Kočevsko in naprej v Belo krajino ter proti jugovzhodu v dolino Krke in Novomeško pokrajino. $\mathrm{V}$ njuni bližini je znano poselitveno jedro $\mathrm{z}$ večjim naseljem in gomilnim grobiščem iz halštatske dobe na Gradišču nad Pijavo Gorico; ${ }^{3}$ Vinji hrib je od njega oddaljen uro hoda, Sloka gora pa poldrugo uro. ${ }^{4}$

3 Vuga 1980, 201 ss; Vuga 1982, 150; Dular, Tecco Hvala 2007, 164 s, sl. 92.

${ }^{4}$ Dular, Tecco Hvala 2007, 198 ss, sl. 115: 53 (Vinji hrib), 55 (Gradišče nad Pijavo Gorico), 62 (Sloka Gora). 


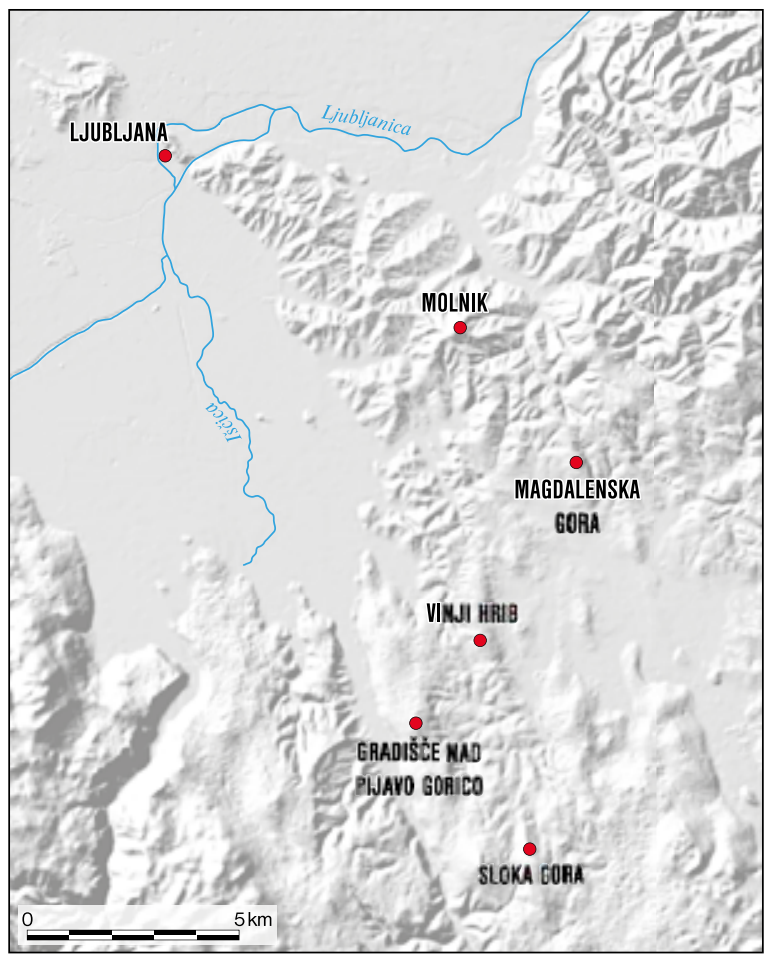

Sl. 1: Geografska lega Vinjega hriba in Sloke gore ter bližnja naselja iz halštatske dobe (po Dular, Tecco Hvala 2007, sl. 82 , kat. št. 53,62 ).

Fig. 1: Geographic position of Vinji hrib and Sloka gora in relation to the near setllements from Hallstatt period (from Dular, Tecco Hvala 2007, Fig. 82, Cat.No. 53, 62).

\section{VINJI HRIB NAD VINOM}

\section{Topografski opis}

Vinji hrib s kopastim vrhom na nadmorski višini 478,4 m leži med vasema Vino na zahodu in Bičje na vzhodu (sl. 2). Hrib je poraščen z mešanim, pretežno listnatim gozdom, čezenj poteka po katastrski meji gozdna pot v smeri S-J. ${ }^{5} \mathrm{~V}$ oblikovanosti terena je okoli vrha dobro zaznaven sklenjen obod naselja $(s l .2,3)$. Okop je močnejši na jugovzhodni strani, kjer ga preseka gozdna pot, na tem mestu je bil morebiti tudi vhod v nekdanjo naselbino, ta ima v tlorisu ovalno obliko s premerom od 150 do 180 $\mathrm{m}$ in meri okoli 1,85 ha. Na lidarskem posnetku se izrazitejši rob nakazuje tudi od 200 do $300 \mathrm{~m}$ nižje po jugovzhodnem pobočju (sl. 2), a ga brez sondiranja ni mogoče kronološko in funkcionalno opredeliti. Morebitno pripadajoče grobišče v bližnji okolici še ni bilo odkrito.

5 Gl. http://gis.arso.gov.si/atlasokolja/profile. aspx?id=Atlas_Okolja_AXL@Arso.

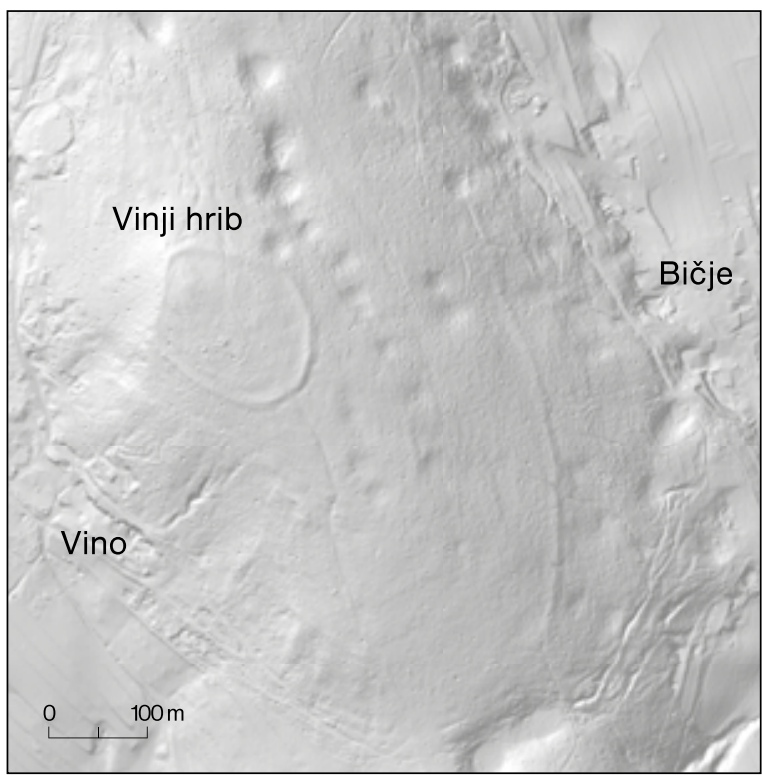

Sl. 2: Lidarski posnetek Vinjega hriba nad Vinom. M. = 1:10 000. (Vir: Lidar (c) ARSO).

Fig. 2: Lidar image of Vinji hrib above Vino. Scale $=1: 10$ 000. (Source: Lidar (C) ARSO).

\section{Stratigrafska slika}

Da bi pridobili podatke, kdaj je bil hrib poseljen, smo na robu terase na severnem delu izkopali $3 \times$ $5 \mathrm{~m}$ veliko sondo (sl. 3). Usmerjena je bila S-J z odklonom 14 stopinj proti vzhodu. Izkopavali smo po režnjih $\mathrm{v}$ mreži kvadrantov $1 \times 1 \mathrm{~m} \mathrm{z}$ izhodiščem v severozahodnem vogalu sonde $(s l .4,5)$. V tem sistemu smo dokumentirali tudi najdbe; višine/ globine so bile merjene od bližnjega parcelnega mejnika in so $\mathrm{v}$ tlorisnem načrtu zabeležene $\mathrm{v} \mathrm{cm}$.

Naravno osnovo sta na območju izkopa sestavljali apnenčasta skala in rdečkasta ilovica (plast 1), ki sta se pojavljali v rahlem nagibu proti severu od 25 do $60 \mathrm{~cm}$ pod današnjim površjem $($ sl. 4,5$)$. Prekrivala ju je rjava ilovnata zemlja (plast 2), ki se je širila $\mathrm{v}$ približno $3 \mathrm{~m}$ širokem pasu od severnega roba $\mathrm{v}$ notranjost sonde. $\mathrm{V}$ njej so bili razpršeni delci lončenih posod (loncev, latvice, pekve) in prežganega ilovnatega stenskega ometa, kos železnega surovca $(t .1)$ ter drobci živalskih kosti in zob. ${ }^{6} \mathrm{Ob}$ zahodnem profilu je na globini $93 \mathrm{~cm}$ ležala razbita pekva v bližini dna pozneje vkopane jame za stojko (sl. $5: \mathrm{x}=2,1 \mathrm{~m}$; y $=1 \mathrm{~m}$; t. 1: 12). Rjavo ilovnato zemljo je v severnem delu

6 Živalske ostanke je določil Borut Toškan (ZRC SAZU, Inštitut za arheologijo, Arheozoološki laboratorij), za kar se mu zahvaljujem. Seznam favne hrani arhiv Inštituta za arheologijo ZRC SAZU. 


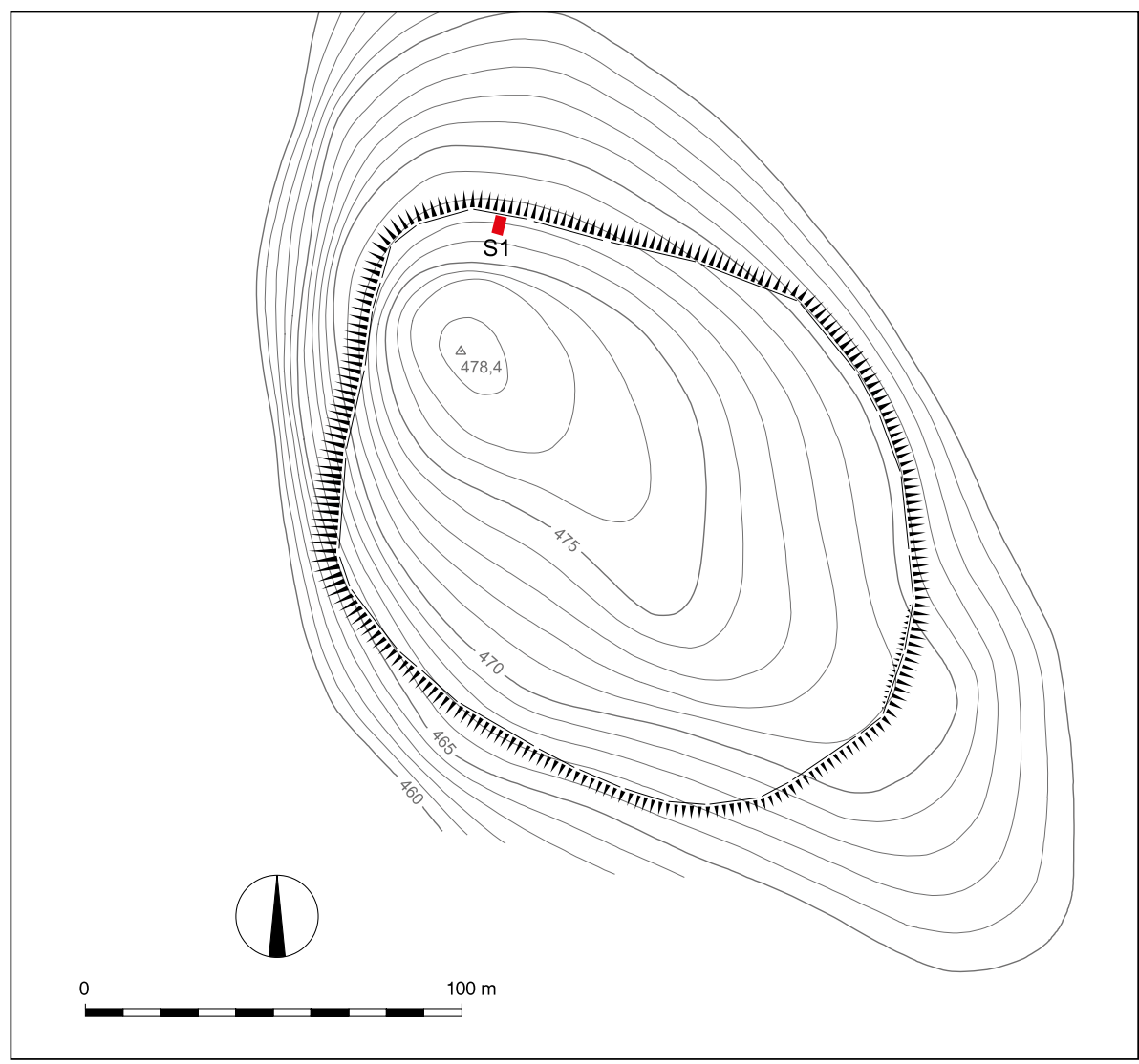

Sl. 3: Vinji hrib nad Vinom. Tloris naselja $\mathrm{z}$ označeno lego sonde 1/1999. M. $=1: 2500$. Fig. 3: Vinji hrib above Vino. Ground plan of settlement with marked location of Trench $1 / 1999$. Scale $=1: 2500$.

sonde preplastilo do $15 \mathrm{~cm}$ debelo peščeno nasutje, pomešano $\mathrm{z}$ ilovico (plast 3 ), s čimer je bil teren poravnan. $\mathrm{V}$ tem nasutju ni bilo najdb, prekrival pa ga je grušč, v katerem je prevladoval kamnit drobir, vmes so bili tudi manjši kamni (plast 4). $\mathrm{Na}$ gruščnati plasti, ki jo razlagamo kot tlak, sta ležala kupa ploščatih kamnov iz rdečega peščenjaka (sl. 5: $\mathrm{x}=0,2-1 \mathrm{~m} ; \mathrm{y}=1,2-2,2 \mathrm{~m}$ ), okoli njiju se je širila kompaktna površina prežgane ilovice $z$ drobci oglja in raztresenimi svitki ter lončenimi črepinjami, kar kaže na to, da se je na tem mestu kurilo oziroma da je bilo tu ognjišče. Na tem območju je bilo pobranih tudi nekaj zoglenelih ostankov prosa (Panicum miliaceum) in ogrščice (Brassica sp.). ${ }^{7}$

V severnih vogalih sonde sta bili odkriti jami za stojki v razmiku približno $2,5 \mathrm{~m}$; obdani sta bili s kamnitimi zagozdami ter zapolnjeni s črno rjavo zemljo in drobci oglja $(s l .4,5)$. Jama v severovzho-

\footnotetext{
${ }^{7}$ Makrobotanične ostanke je opredelila Metka Culiberg (bivša sodelavka Biološkega inštituta Jovana Hadžija ZRC SAZU); gl. Dular, Tecco Hvala 2007, 208-209, sl. 119.
}

dnem vogalu, ki je bila vidna le v profilu, je bila vkopana $30 \mathrm{~cm}$ globoko $v$ gruščnato plast, medtem ko je bila jama $\mathrm{v}$ severozahodnem vogalu malce globlja $(50 \mathrm{~cm})$ in je prebila tlak in peščeno nasutje pod njim ter starejšo kulturno plast vse do mrtvice. Ti jami bi lahko bili ostanka lesene palisade oz. obodne ograde ali pa stavbe, kar se zdi verjetnejše. V razdalji okoli $2,5 \mathrm{~m}$ od severozahodne jame proti jugu je bila namreč odkrita še tretja jama za stojko (sl. $5: \mathrm{x}=2,6 \mathrm{~m} ; \mathrm{y}=1 \mathrm{~m}$ ), vkopana približno enako globoko do mrtvice in prav tako obdana $s$ kamni iz apnenca in peščenjaka. Na gruščnatem tlaku je ležalo precej večjih kamnov, ki so morda ostanki stavbnih temeljev, a jih ni mogoče povezati $\mathrm{v}$ smiseln tloris. Na območju stavbe so bili med gruščem in na njem najdeni deli lončene skodele, motka, svitkov, pa tudi železen nožič ( $t$. $2: 1-12)$, kosi prežganega ilovnatega stenskega ometa ter drobci živalskih kosti in zob, ki pripadajo govedu in drobnici. ${ }^{8}$ Vse te ostaline je zagrnila temnorjava zemlja (plast 5), v kateri so se pojavljali keramični

8 Gl. op. 6. 

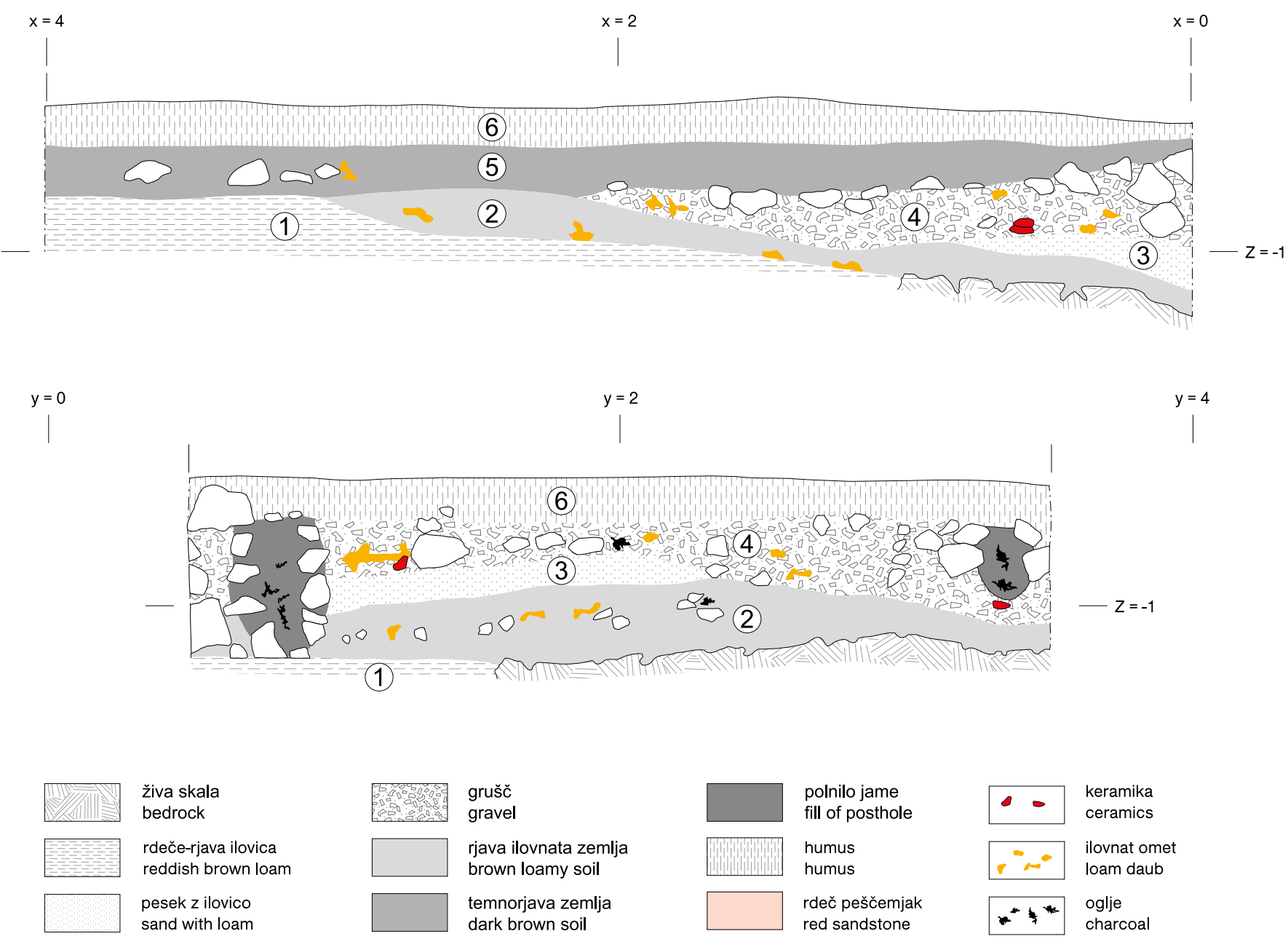

grušč

gravel

rjava ilovnata zemlja

brown loamy soil

temnorjava zemlja

dark brown soil
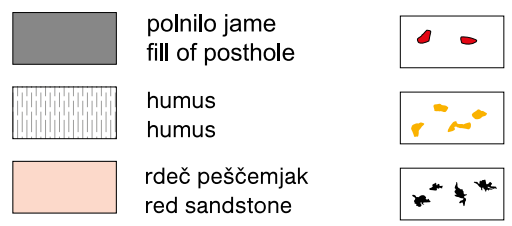

keramika ceramics

Sl. 4: Vinji hrib nad Vinom, sonda 1/1999. A - zahodni profil, B - severni profil. M. = 1:25.

Fig. 4: Vinji hrib above Vino, Trench 1/1999. A - west cross-section, B - north cross-section. Scale = 1:25.

in železni fragmenti ( $t$. 2: 13-17), nastala pa je po opustitvi naselja. Najdbe (ostenja posod, prežgan ilovnat stenski omet) so se sporadično pojavljale še v gozdnem humusu (plast 6).

V sondi odkrite plasti lahko interpretiramo kot ostanke dveh poselitvenih oz. gradbenih faz (sl. 4). Razpršene najdbe v rjavi ilovnati zemlji (plast 2), ki je ležala na naravni skalnati in sterilni ilovnati podlagi, so na območju izkopa edini ostanki starejše poselitve ( $f a z a I$ ). Sledila sta ji izravnava terena s peščenim nasutjem (plast 3 ) in nad njim gruščnato tlakovanje (plast 4), na katerem je bil na samem robu naselja postavljen objekt, grajen s stojkami in z ilovico ometanimi stenami, imel je tudi ognjišče ( $f a z a I I)$. Stavbo je verjetno uničil požar, ruševine pa sta po opustitvi naselja postopno zakrila plast temnorjave zemlje (plast 5) in na vrhu gozdni humus (plast 6).

\section{Časovna opredelitev}

Za datacijo prve poselitvene faze je bolj malo opore, saj med najdbami prevladujejo majhni koščki keramike, ki je slabe kakovosti in zelo drobljiva. Da hrib ni bil poseljen pred železno dobo, bi lahko sklepali po železnem surovcu $(t .1: 2)$ iz najgloblje kulturne plasti 2 . Temu v prid govorijo tudi lonci, pekve in latvice ( $t$. 1: 4-10,12), ki so običajen inventar železnodobnih hiš. Kronološko določnejši je morda reoksidacijsko žgan ročaj $(t$. 1: 7), ki bi kazal na mlajše halštatsko obdobje, kajti takšen postopek žganja v lončarskih pečeh $\mathrm{z}$ redukcijsko atmosfero in končno oksidacijo se je na Dolenjskem razširil prav v tistem času. ${ }^{9}$ Ročaj

9 Dular 1982, 150 s. Tako žgani izdelki so predvsem situle $\mathrm{z}$ nogo in ciboriji tipov 9, 10 in 11, ki so datirani 


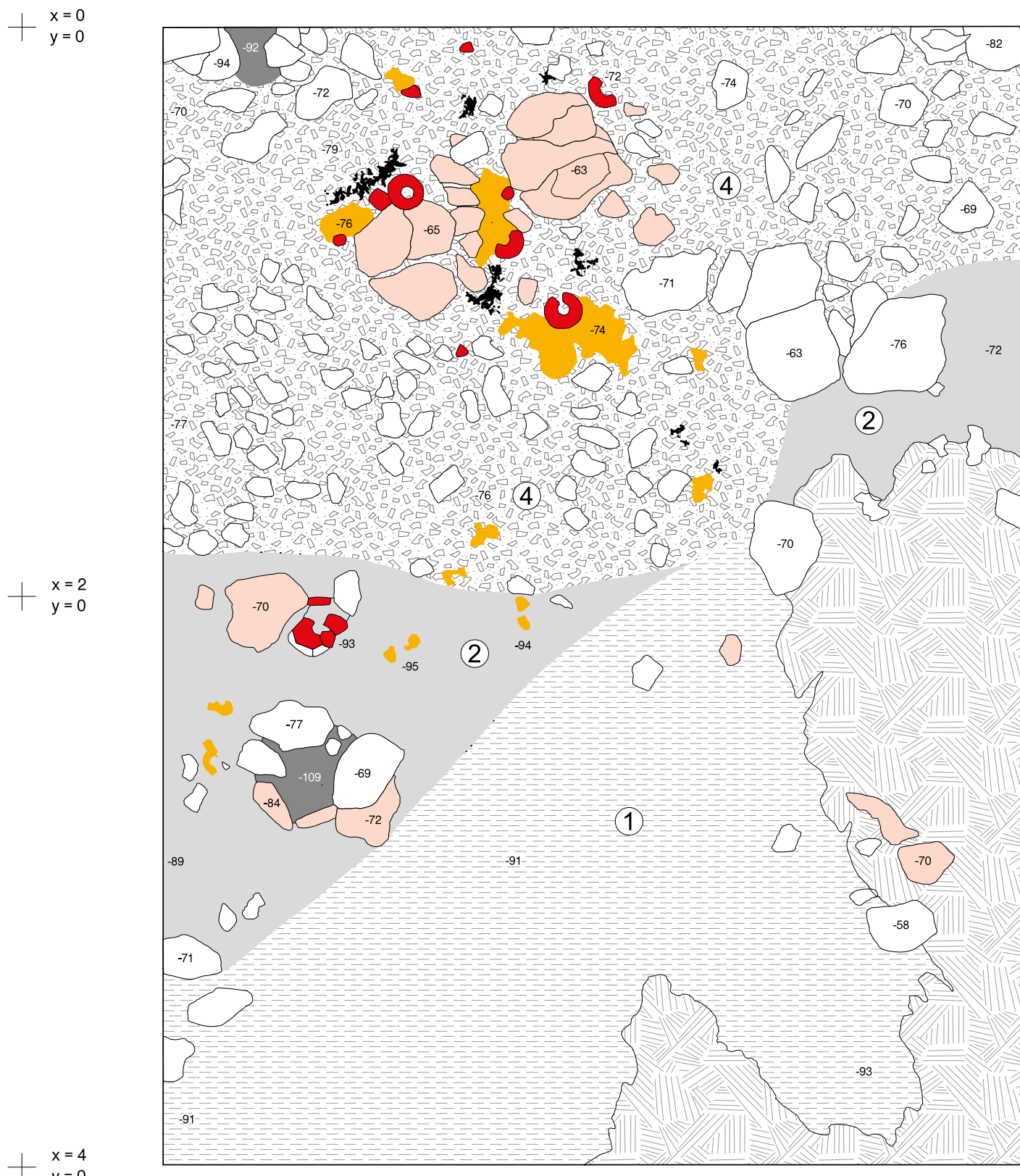

$x=0$
$y=4$

Sl. 5: Vinji hrib nad Vinom, sonda 1/1999. Kumulativni tloris. M. = 1:25.

Fig. 5: Vinji hrib above Vino, Trench 1/1999. Cumulative ground plan. Scale = 1:25.

je bil na posodo verjetno nameščen vodoravno, saj so pokončni ročaji na halštatskodobni keramiki običajno širši in trakasti, ta pa ima okrogel presek. Nekaj primerov vodoravnih ročajev je mogoče zaslediti v grobni keramiki iz Dolenjskih Toplic v dolini reke Krke, datirani pa so v certoško in negovsko stopnjo. ${ }^{10}$ Mladohalštatsko okrasno

$\mathrm{v}$ stopnje kačastih in certoških fibul ter negovskih čelad (ib., 50 ss).

10 Teržan 1976, t. 27: 9; 42: 5; 43:4, za datacijo glej sl. 58 . prvino je mogoče prepoznati tudi na fragmentu ostenja $\mathrm{z}$ udrto bradavico $(t .1: 3) .^{11}$

Drugo poselitveno oz. gradbeno fazo lahko prav tako opredelimo v mladohalštatsko obdobje na osnovi okrasa nalepljene valovnice na fragmentih skodele $\mathrm{z}$ ročajem $(t .2: 3)$. Motiv valovnice se

11 Prim. Dular 1982, t. 6: 41; 7: 58; 8: 63,64 (okras na loncih tipov $1,6,7$, datiranih v certoški in negovski horizont: ib., 28 ss); glej še Grahek 2016, 194 ss, sl. 57: O 7b. 
pojavlja na loncih tipov 6 in 7 po Dularju, ${ }^{12} \mathrm{ki}$ so pogosti v Dolenjskih Toplicah in so tudi po obliki profila podobni skodeli z Vinjega hriba, le da je ta manjša in ima ročaj s sedlastim presekom ter paroma bradavičastih izrastkov na vrhu in pri korenu. Primerjave zanj zopet zasledimo med grobnimi najdbami iz Dolenjskih Toplic iz časa certoške in negovske stopnje. ${ }^{13}$ Iz plasti 4 na Vinjem hribu naj omenimo še fragment motka ( $t$. 2: 5$)$, ki je najbolj podoben primerkoma iz naselbine na Gradcu pri Blečjem vrhu, kjer sta bila najdena v kontekstih, datiranih v certoško stopnjo - eden na robu ognjišča v hiši 1 , drug pa v plasti 15 skupaj $\mathrm{s}$ košaričastim obeskom. ${ }^{14}$ Dobro primerjavo ima tudi v Dolenjskih Toplicah v naselbinskem gradivu iz certoške oz. negovske stopnje. ${ }^{15}$

Med najdbami iz plasti 5 na Vinjem hribu, odloženi po opustitvi naselja, lahko keramični fragment s črno barvanim pasom (t. 2: 17) pripišemo mladohalštatskemu obdobju, ${ }^{16}$ profilirano ustje in dno $(t .2: 14,15)$ pa poznosrednjeveškemu loncu. ${ }^{17}$

Glede na te indice je bil Vinji hrib nad Vinom poseljen v mlajšem halštatskem obdobju, verjetno $\mathrm{v}$ certoški stopnji, in opuščen ob koncu starejše železne dobe. Primerjamo ga lahko denimo z naseljem na Gradcu pri Blečjem vrhu v Posavskem hribovju (sl. 1). Tam sta bili v certoški stopnji prav tako ugotovljeni dve gradbeni fazi, ki ju predstavljajo ostanki hiše 1 in nad njo še druge $z$ gruščnatim tlakom in jamama za stojki s kamnitimi zagozdami ter podobnim inventarjem kot na Vinjem hribu, le da je bil Gradec na Blečjem vrhu prvič poseljen že $\mathrm{v}$ bakreni dobi in nazadnje $\mathrm{v}$ mlajši železni dobi. ${ }^{18}$ Dva stratigrafsko ločena bivalna nivoja iz certoške in negovske stopnje sta bila odkrita tudi na Cvingerju v Dolenjskih Toplicah, ${ }^{19}$ ki je bil prej poseljen $\mathrm{v}$ pozni bronasti dobi, ob koncu starejše železne dobe pa opuščen.

12 Dular 1982, 32 s, t. 7: 58-61; 8: 62,63,65. Prim. še Grahek, Kovač 2020, t. 5: 3; 6: 14.

13 Teržan 1976, t. 6: 1; 75: 5; 78: 12. Prim. še Dular, Ciglenečki, Dular 1995, t. 8: 1; 33: 14; 63: 1; Grahek 2016, 158, 179 ss, 234 ss; sl. 47: Sk 2b; 70: 28.

14 Pavlin 2011, 137 ss, t. 3: 3; 6: 8 .

15 Dular, Križ 2004, 216 s (sonda 1: plast 6), t. 2: 15.

16 Za barvano keramiko gl. Dular 1982, 90 s; Grahek 2016, 218 ss.

17 Prim. npr. Štular 2007, 376 ss, tab. 1: tip 11, sl. 10; Porenta et al. 2015, 341 s, sl. 10b.

18 Pavlin 2011, 131 ss, sl. 7-14.

19 Dular, Križ 2004, 219 ss (sonda 2: plast 5 in zid), 223 ss (sonda 3: plasti 5 in 6).

\section{GRADIŠČE NA SLOKI GORI}

\section{Topografski opis}

Toponim Gradišče se nanaša na ozek razpotegnjen hrbet, ki se blago vzpenja severno od današnjega naselja Sloka Gora in ima značilno dinarsko smer SZ-JV (sl. 6). Severni del je danes porasel z mešanim gozdom; na južnem delu, kjer doseže najvišjo točko na nadmorski višini $633,5 \mathrm{~m}$, se širijo travniki, v preteklosti pa so bile tod njive.

Pod vrhom na južnem delu poteka oddvojni okop $(s l .6,7)$, okop je viden tudi na severnem delu hrbta, manj izrazit je obod naselja na vzhodnem in zahodnem pobočju. Njegova notranjost je bila deloma preoblikovana $\mathrm{v}$ več manjših teras, ki so domnevno nastale $\mathrm{z}$ recentnim obdelovanjem, medtem ko sta okopa prazgodovinska, ocenjena površina tedanje naselbine pa znaša približno 1,84 ha. Na severozahodnem pobočju se na lidarskem posnetku nakazuje še ježa (sl. 6), ki je verjetno rob nekdanje njive. V bližnji okolici hriba doslej še ni bilo ugotovljeno pripadajoče grobišče.

\section{Stratigrafska slika}

S sondo v velikosti $3 \times 5 \mathrm{~m}$ in usmerjeno $\mathrm{S}-\mathrm{J}$ z odklonom 15 stopinj proti vzhodu (sl. 7) smo

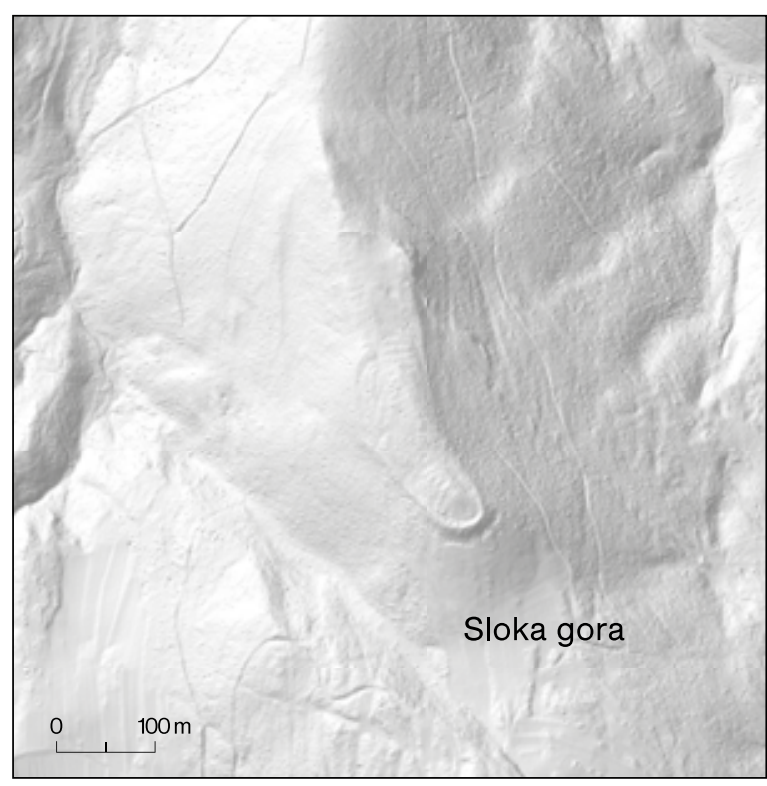

Sl. 6: Lidarski posnetek Sloke gore. M. = 1:10 000. (Vir: Lidar (C) ARSO).

Fig. 6: Lidar image of Sloka gora. Scale $=1: 10$ 000. (Source: Lidar (c) ARSO). 


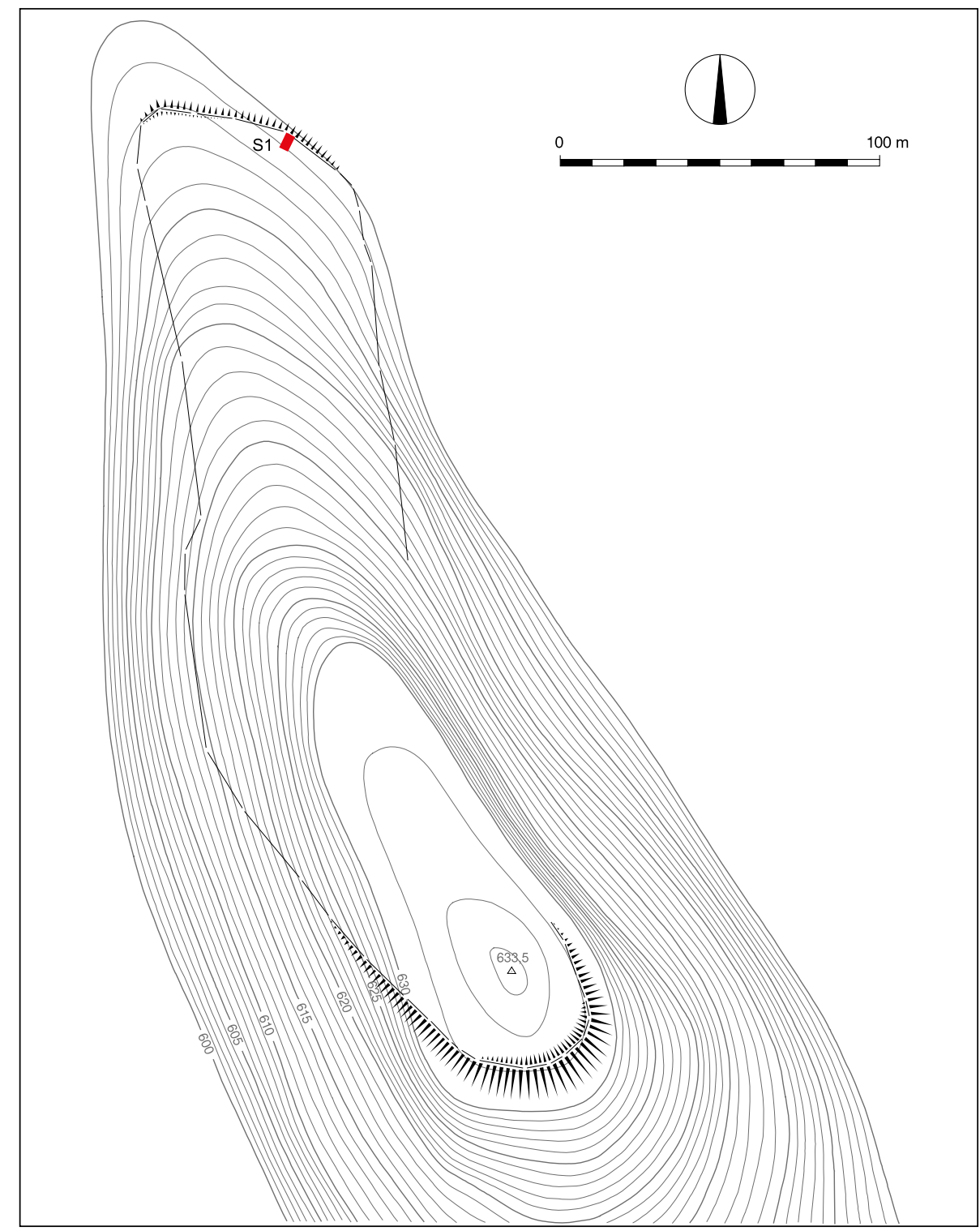

Sl. 7: Gradišče na Sloki gori. Tloris naselja z označeno lego sonde 1/1999. M. = 1:2500.

Fig. 7: Gradišče at Sloka gora. Ground plan of settlement with marked location of Trench $1 / 1999$. Scale $=1: 2500$.

preiskali rob na severnem koncu naselja - na mestu, kjer smo pričakovali, da se je zaradi padca terena za okopom zadržalo največ plasti. Dokumentiranje ostalin in najdb je potekalo na enak način kot na Vinjem hribu nad Vinom; v terenski dokumentaciji zabeležene višine/globine so relativne, merjene od fiksne točke na robu naselja, ki ji nismo izmerili absolutne nadmorske višine.

Preperela apnenčasto dolomitna raščena skala in sterilna rdečkasta ilovica nad njo (plast 1) sta se na območju izkopa pojavljali na globinah od 30 do $90 \mathrm{~cm}$ pod današnjim površjem $(s l .8,9)$. $\mathrm{V}$ severnem delu sonde je mrtvico preplastila temnorjava ilovnata zemlja (plast 2) v približno meter širokem pasu (sl. 8); v njej so bili razpršeni kosi prežgane gline, delci lončenih posod, svitki in kremenov odbitek (t. 3: 1-3). Ob zahodnem robu sonde se je nad sterilno ilovico kazala manjša zaplata rumene ilovnate zemlje (plast 3) z drobci prežganega ilovnatega stenskega ometa. Obe kulturni plasti je prekrivalo gruščnato nasutje (plast 4), ki je bilo debelejše ob severnem robu in se je tanjšalo proti sredini sonde. V njem je bilo veliko prežganega stenskega ometa, koščki oglja in deli pekev, prenosne pečke, svitka, cedila in predilnega vretenca ( $t$. 3: 4-9); prav tako so bili najdeni ostanki živalskih kosti in zob, pripisani drobnici. Čez gruščnat tlak se je v severnem delu širila groblja 

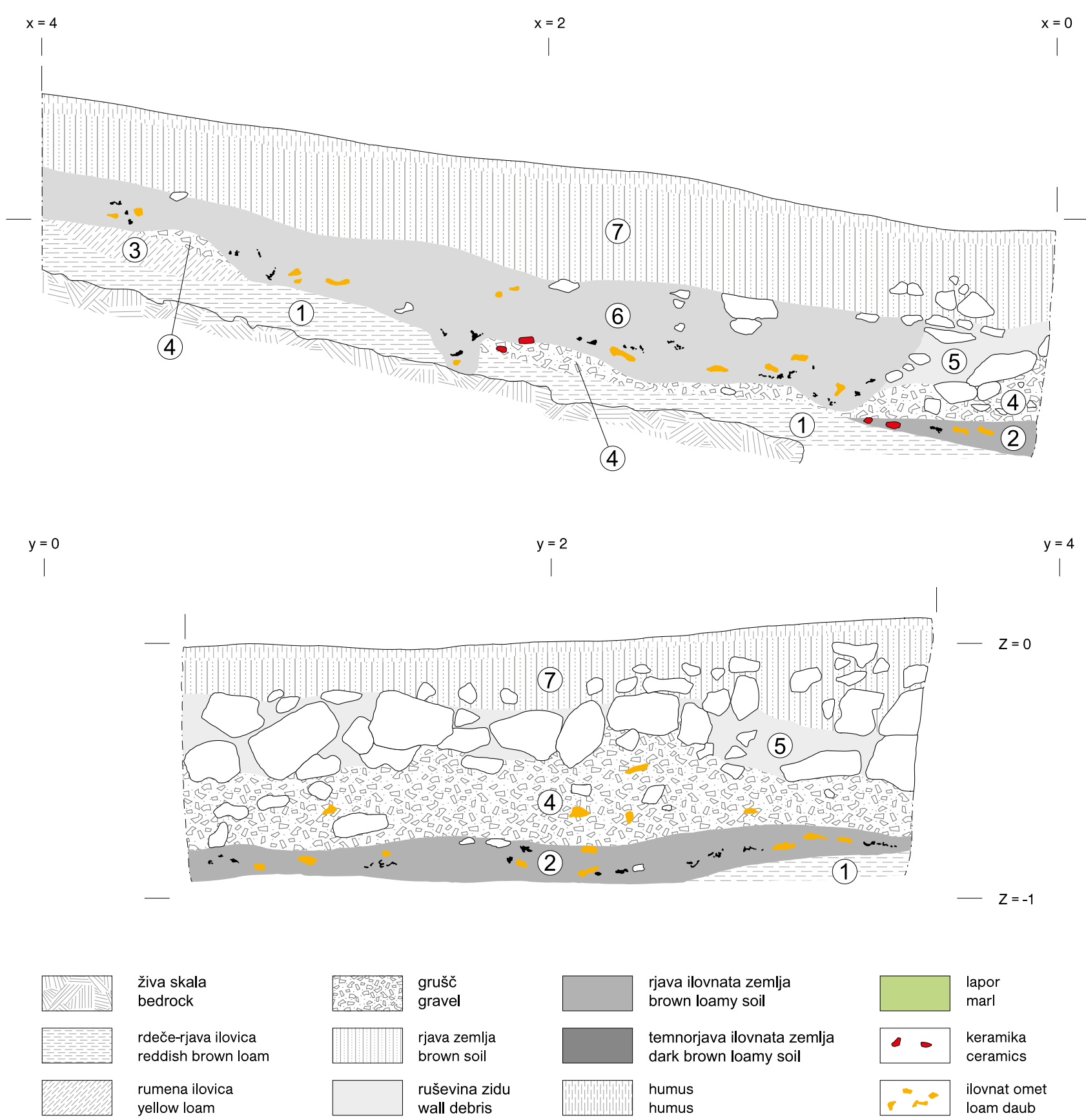

Sl. 8: Gradišče na Sloki gori, sonda 1/1999. A - zahodni profil, B - severni profil. M. = 1:25.

Fig. 8: Gradišče at Sloka gora, Trench 1/1999. A - west cross-section, B - north cross-section. Scale = 1:25.

večjih in manjših kamnov z drobirjem (plast 5), ki bi jih lahko pripisali razrušenemu zidu, čeprav na območju sonde nismo odkrili njegovega kompaktnejšega jedra z notranjim in zunanjim licem. Med kamni so bili najdeni drobci kosti goveda in pasji zob. ${ }^{20} \mathrm{Za}$ to kamnito grobljo, v kateri so se poleg apnenčastih pojavljali tudi posamični

$$
20 \text { Gl. op. } 6 .
$$

lapornati kamni in peščenjaki, se je vlekla debela plast rjave ilovnate zemlje (plast 6). V notranjosti sonde sta se $\mathrm{v}$ prepereli dolomitni osnovi nakazovali dve plitki kotanji (sl. 9: $\mathrm{x}=2 \mathrm{~m}$; $\mathrm{y}=2,5$ in $3,4 \mathrm{~m}$ ); ali sta naravni ali delo človeških rok, ni mogoče z gotovostjo reči, saj poglobitvi nista imeli pravilne oblike niti jasnih robov. V nadaljevanju linije, ki sta jo nakazovali kotanji, so v smeri proti zahodnemu profilu ležali trije kamni. $\mathrm{Na}$ 


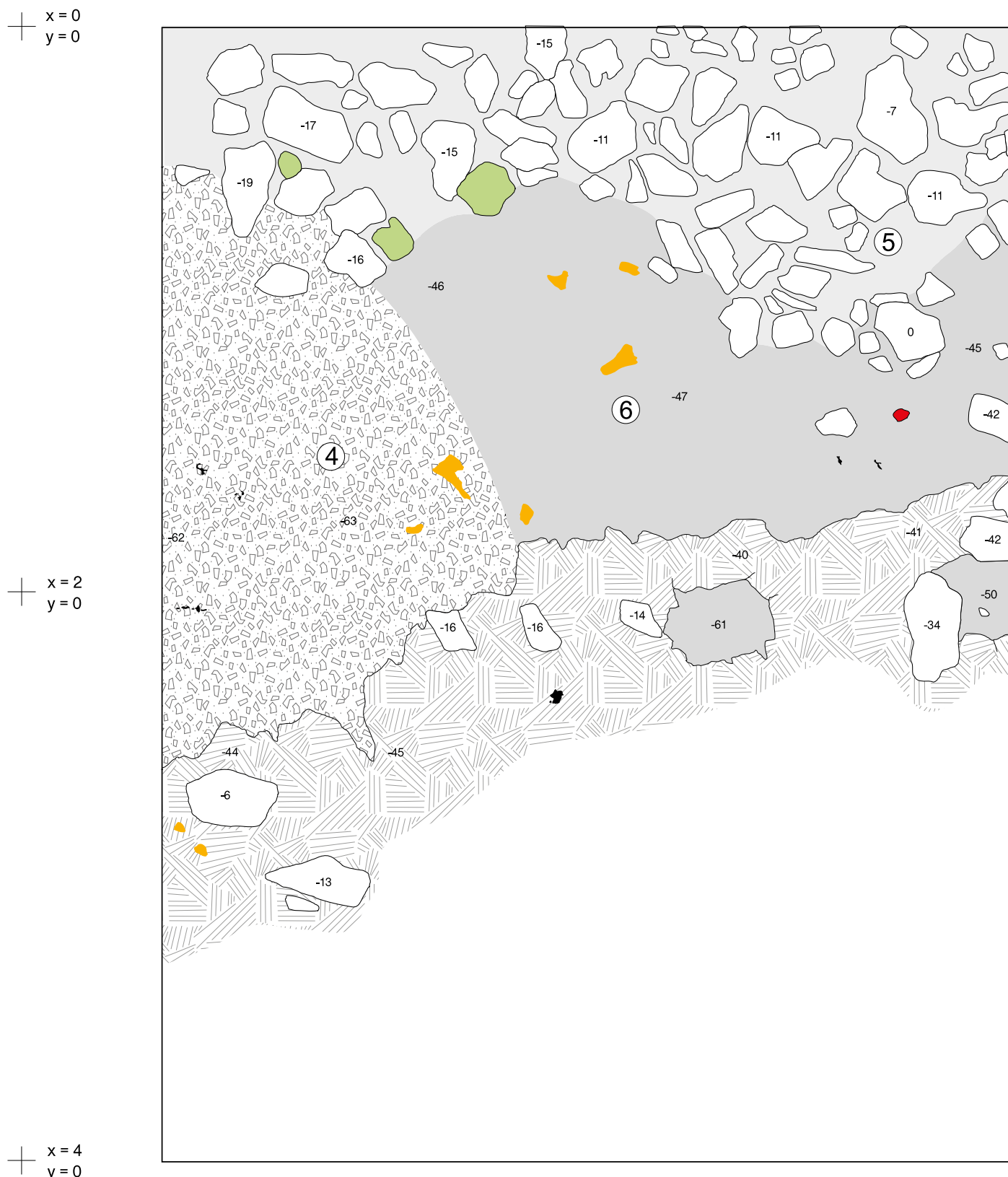

Sl. 9: Gradišče na Sloki gori, sonda 1/1999. Kumulativni tloris. M. = 1:25.

Fig. 9: Gradišče at Sloka gora, Trench 1/1999. Cumulative ground plan. Scale = 1:25.

tej liniji je bil v zahodnem profilu viden manjši vkop (morda jama za kol), ki je prebil gruščnato plast in segel $\mathrm{v}$ mrtvico vse do raščene skale pod njo (sl. $8: \mathrm{x}=2,3 \mathrm{~m}$ ). Glede na lego bi kotanji in vkop lahko pripisali nekakšni konstrukciji, oprti na stojke. Dna kotanj in vkopa so bila namreč na približno isti globini, zapolnjevala pa jih je enaka rjava ilovnata zemlja (plast 6), ki se je nabrala nad gruščnatim tlakom. V tej plasti je bilo precej keramičnih najdb, med njimi delci ustij, ostenij in dna posod, držajev, masivnejša noga, kosi prenosne pečke, uteži za statve ali ognjiščne koze in motek (t. 3: 10-13; 4: 1-7); najdeni so bili tudi zobje in kosti drobnice in goveda. Vse skupaj je zagrnila rjava zemlja, prepredena $\mathrm{z}$ drevesnimi koreninami (plast 7), blizu severnega roba izkopa se je v njej pojavljalo še nekaj večjih kamnov (ruševina zidu?) in keramičnih najdb ( $t$. 4: 8-10).

Stratigrafija kaže na dve poselitveni ali gradbeni fazi (sl. 8). Ostanek prve sta kulturni plasti 2 in 3 temnorjave in rumene ilovnate zemlje (faza I), ki sta ležali neposredno na geološki podlagi. $\mathrm{V}$ njih nismo zasledili stavbnih ostankov niti sledov obrambnega nasipa ali obzidja, zato sklepamo, da 
naselje takrat ni bilo utrjeno. Drugi poselitveni akt (faza II) je mogoče videti v gruščnatem nasutju (plast 4), s čimer se je izoblikovala nova hodna površina. $\mathrm{Na}$ robu naselja je bil nanj domnevno postavljen obrambni zid, ki se je čez čas razrušil (plast 5). Ob njem je bil nemara s stojkami zgrajen objekt, kar nakazujejo vkop skozi grušč v mrtvico in kotanji v živi skali. Rjavo ilovnato zemljo (plast 6), ki se je raztezala za ruševinami zidu v notranjost sonde in je vsebovala največ najdb, interpretiramo kot ruševinsko plast druge poselitvene faze. Rjava zemlja nad njo (plast 7) pa se je nabrala sčasoma po opustitvi naselja.

\section{Časovna opredelitev}

Razen glinastih svitkov (t. 3: 1,3), ki niso manjkali skorajda v nobeni halštatskodobni hiši, ni za datacijo prve poselitvene faze nobenih oprijemljivejših elementov. Za kronološko opredelitev druge faze pa se lahko opremo na fragment keramičnega cedila in odlomljen ročaj pekve $\mathrm{z}$ izrastkoma pri korenu (t. 3: 4,7) iz gruščnatega tlaka (plast 4) ter na del prenosne pečke $\mathrm{z}$ nalepljeno valovnico, masivno nogo lončene posode in motek ( $t .3: 10,13 ; 4: 3)$ iz plasti nad tlakom (plast 6), ki imajo najboljše analogije v Dolenjskih Toplicah v dolini reke Krke, belokranjskem Podzemlju in na Blečjem vrhu v Posavskem hribovju.

Podoben košček cedila je bil na Cvingerju v Dolenjskih Toplicah najden $\mathrm{v}$ plasti, datirani $\mathrm{v}$ certoško oz. negovsko stopnjo, ${ }^{21}$ primerjave zanj zasledimo še v drugih naselbinskih kontekstih iz mlajšega halštatskega obdobja, denimo na Kučarju pri Podzemlju, Kunklu pod Vrhtrebnjem in Cvingerju nad Virom pri Stični. ${ }^{22}$ V plasteh iz tega časa so na Cvingerju v Dolenjskih Toplicah in na Kučarju pri Podzemlju zastopane tudi masivne noge posod. ${ }^{23}$ Ročaj pekve s parom izrastkov pri korenu pa ima najboljše analogije $\mathrm{v}$ mladohalštatskem naselbinskem gradivu z Gradca pri Blečjem vrhu, ${ }^{24}$ medtem ko se v Stični podobni ročaji pojavljajo pretežno v starejšem halštatskem obdobju. ${ }^{25} \mathrm{O}$ valovnici kot značilni okrasni prvini na keramiki

${ }^{21}$ Dular, Križ 2004, 224 (sonda 3, plast 6), t. 10: 11.

${ }^{22}$ Dular, Ciglenečki, Dular 1995, t. 72: 18; Dular et al. 1991, t. 2: 1; Grahek 2016, 163, sl. 48: pos. obl. 1, t. 29: 2.

${ }^{23}$ Dular, Križ 2004, t. 11: 13; Dular, Ciglenečki, Dular 1995, t. 10: 5 .

${ }^{24}$ Pavlin 2011, t. 3: 8; 6: 1.

25 Grahek 2016, 180, sl. 51: Pe 8. certoške in negovske stopnje ter o motkih pa je že tekla beseda $\mathrm{v}$ zvezi $\mathrm{z}$ datiranjem najdb druge poselitvene faze na Vinjem hribu nad Vinom. ${ }^{26}$ Glede na njune skupne značilnosti (primerljiva velikost naselja in bivalni ostanki) domnevamo, da je bil življenjski cikel gradišča na Sloki gori enak tistemu na Vinjem hribu.

\section{SKLEP}

Sondiranje na Vinjem hribu nad Vinom in Gradišču na Sloki gori je kljub majhnemu obsegu in skromnim najdbam potrdilo domnevo o njuni obljudenosti v prazgodovini. Uvrščata se v skupino višinskih naselij s površino manjšo od 2 ha, ki so nastala v mlajšem halštatskem obdobju na severnem in severozahodnem obrobju teritorija dolenjske halštatske skupnosti. ${ }^{27}$ Grobišča pri nekaterih med njimi prav tako niso bila ugotovljena niti niso vidne gomile v njihovi bližnji okolici, ${ }^{28}$ morebiti je šlo za plane grobove, ki jih v konfiguraciji terena ni mogoče zaznati. To možnost nakazujeta nedavno odkrita plana grobova iz zgodnje negovske stopnje pod Kovkom nad Hrastnikom. ${ }^{29}$ Iz časa, kamor datiramo naselji na Vinjem hribu in Sloki gori, je v Posavskem hribovju znanih še več takih primerov. ${ }^{30}$ Potemtakem niti ni tako zelo nenavadno, da v njuni okolici ni gomil, kvečjemu bi to lahko bil le še dodaten argument za predlagano kronološko opredelitev.

Po dosedanjih dognanjih je $\mathrm{v}$ zahodnih predelih Dolenjske in $\mathrm{v}$ Zasavju zraslo $\mathrm{v}$ mlajšem halštatskem obdobju vsaj dvajset novih naselij, s čimer se je poselitveni vzorec spremenil v primerjavi s starejšim halštatskim obdobjem. ${ }^{31}$ Novonastala naselja so povečini manjša in imajo v okolici bolj malo kakovostne zemlje za obdelovanje, umeščena pa so v bližino rudonosnih območij. ${ }^{32}$ Morda je bilo pridobivanje železa in barvnih kovin eden od

${ }^{26} \mathrm{Za}$ analogije glej op. 12, 14 in 15.

27 Dular, Tecco Hvala 2007, 71-73, sl. 24: skupini V in VI; ter novoodkrito naselje Kovk nad Hrastnikom: Božič, Gaspari, Pirkmajer 2020, sl. 3.

28 Dular, Tecco Hvala 2007, 143 ss, prim. sl. 82 in 83, npr. Gradišče nad Dešnom (kat. št. 6), Gradec pri Blečjem vrhu (kat. št. 44), Zagrac nad Vodicami pri Gabrovki (kat. št. 123).

29 Božič, Gaspari, Pirkmajer 2020.

30 Draksler 2007, 149 ss, sl. 45; prim. še Dular, Tecco Hvala 2007, 126 ss, sl. 73 (skupina III).

31 Dular, Tecco Hvala 2007, 143 ss, sl. 82.

32 Ib., 204-205, 213-215, sl. 117, 124. 
ekonomskih motivov in virov preživljanja njihovih prebivalcev, morda pa so na novo poselitev vplivali drugi strateški razlogi, na katere namiguje prostorska razporeditev najdb negovskih čelad in njihovo pojavljanje celo v okviru manjših naselij, kot je denimo Kovk nad Hrastnikom, kar bi kazalo na premeščanje vojaške moči in okrepljeno varovanje meja teritorija dolenjske halštatske skupnosti ob koncu starejše železne dobe. ${ }^{33}$

33 Teržan 2008, 320 ss, sl. 61; ead. 2020, 366-367; Dular 2020, 403-404, 410; Grahek, Kovač 2020, 449; Božič, Gaspari, Pirkmajer 2020, 515; Tecco Hvala 2017, 128 ss, sl. 99.

\section{KATALOG NAJDB}

Najdbe hrani Narodni muzej Slovenije. Vsa keramika je prostoročno izdelana, razen poznosrednjeveških posod (t. 2: 14,15).

\section{Vinji hrib nad Vinom}

\section{Tabla 1}

1. retuširan odbitek iz roženca. Inv. št. P 30104.

2. frag. železnega surovca. Inv. št. P 30114.

3. frag. posode iz grobozrnate gline $z$ nalepljeno bradavico; površina hrapava; barva zunaj rdečerjava, znotraj temnorjava; oksidacijsko žgano. Inv. št. P 30105.

4. frag. latvice iz fine gline; površina zglajena; barva zunaj in znotraj rjava; oksidacijsko žgano. Inv. št. P 30110.

5. frag. lonca iz grobozrnate gline; površina glajena; barva zunaj temnorjava lisasta, znotraj rdečerjava; oksidacijsko žgano. Inv. št. P 30108.

6. frag. lonca iz grobozrnate gline; površina hrapava; barva zunaj rjava, znotraj rdečerjava; oksidacijsko žgano. Inv. št. P 30109.

7. frag. ročaja iz drobnozrnate gline; površina hrapava; barva zunaj svetlorjava, sredica črna; redukcijsko žgano s končno oksidacijo. Inv. št. P 30113.

8. frag. posode iz grobozrnate gline; površina glajena; barva zunaj in znotraj rdečerjava; oksidacijsko žgano. Inv. št. P 30106.

9. frag. posode iz drobnozrnate gline; površina glajena; barva zunaj črna, znotraj svetlorjava; nepopolno redukcijsko žgano. Inv. št. P 30107.

10. frag. posode iz drobnozrnate gline; površina hrapava; barva zunaj in znotraj rdečerjava; oksidacijsko žgano. Inv. št. P 30112.

11. držaj posode iz finozrnate gline; površina hrapava; barva rdečerjava; oksidacijsko žgano. Inv. št. P 30111.

12. frag. pekve iz drobnozrnate gline; površina hrapava; barva zunaj in znotraj rdečerjava; oksidacijsko žgano. Inv. št. P 30115.

\section{Tabla 2}

1. frag. železen ukrivljen nož. Inv. št. P 30122.

2. frag. posodice iz drobnozrnate gline; površina hrapava; barva zunaj črna, znotraj rjava lisasta; nepopolno redukcijsko žgano. Inv. št. P 30119.

3. frag. skodela iz grobozrnate gline; površina hrapava; barva zunaj svetlorjava, znotraj temnorjava; redukcijsko žgano s končno oksidacijo; okras: nalepljene valovnice; pod ustjem je pritrjen trakast ročaj sedlastega preseka, ki ima na vrhu in pri korenu po dva izrastka na vsaki strani. Inv. št. P 30116-30118.

4. frag. železnega predmeta. Inv. št. P 30121.

5. frag. motka iz grobozrnate gline; površina hrapava; barva rjava; oksidacijsko žgano. Inv. št. P 30120.

6. frag. lonca iz grobozrnate gline; površina hrapava; barva zunaj črnorjava, znotraj rdečerjava; oksidacijsko žgano s končnim dimljenjem. Inv. št. P 30123.

7-12. frag. svitkov iz grobozrnate gline; površina hrapava; barva rdečerjava; oksidacijsko žgano. Inv. št. P 30124-30129.

13. frag. železnega tulca. Inv. št. P 30130.

14. frag. lončka iz drobnozrnate gline; izdelan na vretenu; površina hrapava; barva zunaj rumena, znotraj siva; trdo žgano. Inv. št. P 30133.

15. frag. lonca iz drobnozrnate gline, izdelan na vretenu; površina porozna; barva zunaj in znotraj rumenosiva; trdo žgano. Inv. št. P 30131.

16. držaj posode iz drobnozrnate gline; površina hrapava; barva rdečerjava; redukcijsko žgano s končno oksidacijo. Inv. št. P 30132.

17. frag. posode iz drobnozrnate gline; površina hrapava; barva zunaj rdeča s črnim premazom, znotraj črna; oksidacijsko žgano. Inv. št. P 30134.

\section{Gradišče na Sloki gori}

\section{Tabla 3}

1. frag. svitka iz grobozrnate gline; površina hrapava, zlizana; barva svetlorjava, sredica siva; nepopolno oksidacijsko žgano. Inv. št. P 30082.

2. kremenov odbitek. Inv. št. P 30081.

3. frag. svitka iz grobozrnate gline; površina hrapava, zlizana; barva svetlorjava; oksidacijsko žgano. Inv. št. P 30083.

4. frag. pekve $z$ začepljenim ročajem iz grobozrnate gline z izrastkoma na korenu; površina hrapava; barva rdečerjava; oksidacijsko žgano. Inv. št. P 30084.

5. frag. prenosne pečke iz grobozrnate gline; površina hrapava, razpokana; barva rjava; oksidacijsko žgano. Inv. št. P 30086. 
6. frag. svitka iz grobozrnate gline; površina hrapava, zlizana; barva rdeča, sredica siva; nepopolno oksidacijsko žgano. Inv. št. P 30085.

7. frag. cedila iz drobnozrnate gline; površina hrapava; barva rdečerjava; oksidacijsko žgano. Inv. št. P 30087.

8. frag. vijček iz grobozrnate gline; površina gladka; barva rjava; oksidacijsko žgano. Inv. št. P 30089.

9. frag. pekve iz grobozrnate gline; površina hrapava, razpokana; barva zunaj rdečerjava, znotraj temnorjava; oksidacijsko žgano. Inv. št. P 30088.

10. frag. prenosne pečke iz grobozrnate gline; površina hrapava, razpokana; barva rdečerjava; oksidacijsko žgano; okras: nalepljena valovnica. Inv. št. P 30090.

11. držaj posode iz grobozrnate gline; površina hrapava, razpokana; barva rjava; nepopolno oksidacijsko žgano. Inv. št. P 30092.

12. frag. ognjiščne koze z nalepljenim rebrom iz grobozrnate gline; površina hrapava, razpokana; barva rdečerjava; oksidacijsko žgano. Inv. št. P 30091.

13. frag. noga posode iz grobozrnate gline; površina hrapava; barva temnorjava, lisasta; nepopolno oksidacijsko žgana; inv. št. P 30093.

\section{Tabla 4}

1. frag. lonca iz drobnozrnate gline $\mathrm{z}$ vodoravno kaneluro pod ustjem; površina glajena; barva rjavočrna; redukcijsko žgano. Inv. št. P 30094.

2. frag. lonca iz drobnozrnate gline; površina glajena; barva rjavočrna; redukcijsko žgano. Inv. št. P 30095.

3. frag. motek iz grobozrnate gline; površina hrapava, razpokana; barva rdeča; oksidacijsko žgano. Inv. št. P 30097.

4. frag. pekve z začepljenim ročajem iz grobozrnate gline; površina hrapava; barva rdečerjava; oksidacijsko žgano. Inv. št. P 30098.

5. frag. lonca iz grobozrnate gline; površina hrapava; barva zunaj rjava, znotraj črna; oksidacijsko žgano. Inv. št. P 30099.

6. jezičast držaj posode iz grobozrnate gline; površina glajena; barva rjavočrna; redukcijsko žgano. Inv. št. P 30100.

7. frag. posode iz grobozrnate gline $\mathrm{z}$ nalepljeno bradavico; površina hrapava; barva rjavočrna; redukcijsko žgano. Inv. št. P 30096.

8. frag. sklede iz fine gline; površina gladka, kredasta; barva rumenorjava; oksidacijsko žgano. Inv. št. P 30101.

9. frag. lonca iz drobnozrnate gline; površina gladka; barva črna; trdo redukcijsko žgano. Inv. št. P 30102.

10. frag. posode iz grobozrnate gline; površina hrapava; barva zunaj črna, znotraj rjava; trdo redukcijsko žgano; okras: plitve poševne kanelure. Inv. št. P 30103.WW

DULAR et al. 1991 = Dular, J., B. Križ, D. Svoljšak, S. Tecco Hvala 1991, Utrjena prazgodovinska naselja v Mirenski in Temeniški dolini (Befestigte prähistorische Siedlungen in der Mirenska dolina und in der Temeniška dolina). - Arheološki vestnik 42, 65-198.

GRAHEK, L. 2016, Stična. Železnodobna naselbinska keramika / Iron Age Settlement Pottery. - Opera Instituti Archaeologici Sloveniae 32. [https://doi. org/10.3986/9789612549244]

GRAHEK, L., O. KOVAČ 2020, Podzemelj - železnodobno središče v Beli krajini v luči novih raziskav (Podzemelj - an Iron Age centre in Bela krajina, in the light of new research). - Arheološki vestnik 71, 435-467. [https://doi. org/10.3986/AV.71.15]

PAVLIN, P. 2011, Prazgodovinsko višinsko naselje Gradec pri Blečjem Vrhu na Dolenjskem / The prehistoric hilltop settlement of Gradec near Blečji Vrh in Dolenjska. Arheološki vestnik 62, 131-163.

PORENTA et al. 2015 = Porenta, S., B. Štular, B. Toškan, Z. Mileusnić, J. Dirjec 2015, Poznosrednjeveško in zgodnjenovoveško najdišče Župnijski dom v Šentvidu pri Stični. Analiza lončenine in živalskih ostankov / The Late Medieval and Early Post-Medieval site of Župnijski dom in Šentvid pri Stični. Analysis of the pottery and animal remains. - Arheološki vestnik 66, 333-397.

PUŠ, I. 1975, Bičje, Vino. - V / In: Arheološka najdišča Slovenije, 194, 195, Ljubljana.

STARE, V. 1975, Sloka gora. - V / In: Arheološka najdišča Slovenije, 238, Ljubljana.
Opera Instituti Archaeologici Sloveniae 1. [https://doi. org/10.3986/9789610503002] 
ŠTULAR, B. 2007, Lonci v opremi visokosrednjeveške kuhinje s kamniškega Malega gradu / High medieval kitchen pottery. The Kamnik Mali grad case study. Arheološki vestnik 58, 375-404.

TECCO HVALA, S. (ur. / ed.) 2017, Molnik pri Ljubljani v železni dobi / The Iron Age site at Molnik near Ljubljana. - Opera Instituti Archaeologici Sloveniae 36. [https:// doi.org/10.3986/9789610503750]

TERŽAN, B. 1976, Certoška fibula (Die Certosafibel). Arheološki vestnik 27 (1977), 317-443.

TERŽAN, B. 2008, Stiške skice / Stična-Skizzen. - V / In: S. Gabrovec, B. Teržan, Stična II/2. Gomile starejše železne dobe. Razprave / Grabhügel aus der älteren Eisenzeit. Studien, Katalogi in monografije 38 (2010), 189-325.

TERŽAN, B. 2020, Dolenjska halštatska skupina. Uvodnik in kratek oris / The Dolenjska Hallstatt Group. An introduction and brief outline. - Arheološki vestnik 71, 361-394. [https://doi.org/10.3986/AV.71.12]

VUGA, D. 1980, Železnodobna najdišča v kotlini Ljubljanskega barja (Iron Age Sites in the Ljubljansko barje (marshland) basin). - Zbornik posvečen Stanetu Gabrovcu ob šestdesetletnici, Situla 20-21, 199-210.

VUGA, D. 1982, Gradišče nad Pijavo Gorico. - Varstvo spomenikov 24, 150.

\section{Gradišče on Sloka gora and Vinji hrib above Vino on the north-western edge of the Dolenjska Hallstatt community}

\section{Summary}

In 1999, as part of the research on prehistoric fortified settlements in the Dolenjska region, the team of the Institute of Archaeology ZRC SAZU test excavated Vinji hrib above Vino and Gradišče on Sloka gora, where prehistoric settlements are mentioned in sources from the end of the $19^{\text {th }}$ and the first decades of the $20^{\text {th }}$ century. They are located in the south-eastern hilly hinterland of Ljubljana (Fig. 1), between two valleys, along which the main traffic routes lead from Ljubljana Basin to Kočevsko and further to Bela krajina region in the south and to the Krka Valley and Novo mesto region in the south-east. In their vicinity, a Hallstatt period centre is known in Gradišče nad Pijavo gorico, which consists of a larger settlement and a tumulus cemetery, Vinji hrib is an hour's walk away, and Sloka gora an hour and a half.

\section{Vinji hrib above Vino}

The hill named Vinji hrib has a domed peak at an altitude of $478.4 \mathrm{~m}$ asl (Fig. 2). The closed perimeter of the settlement around the summit is clearly visible in the terrain (Figs. 2; 3). The rampart is stronger on the south-eastern side, where it is crossed by a forest path. At this spot there might have been an entrance to the prehistoric settlement, which, in its ground plan, has an oval shape with a diameter of 150 to $180 \mathrm{~m}$ and measures about $1.85 \mathrm{ha}$. The LiDAR image also suggests a more pronounced contour 200 to $300 \mathrm{~m}$ lower along the south-eastern slope (Fig. 2), but this cannot be determined chronologically and functionally without test excavation. A possible cemetery in the vicinity has not yet been discovered.

In order to obtain data on when the hill was inhabited, we excavated a $3 \times 5 \mathrm{~m}$ trench in the northern part at the edge of the terrace (Figs. 3-5). The layers revealed in the trench can be interpreted as the remains of two settlement or construction phases. Scattered finds in brown loam (Layer 2), which were found directly above a natural deposit of bedrock and sterile loam, are the only remains of an earlier settlement in the excavation area (Phase I). This was followed by the levelling of the terrain with a sandy Layer 3 and, above it, the gravel floor (Layer 4), on which a building was erected at the outermost edge of the settlement. It was constructed with wooden post and walls plastered with clay and also had a hearth (Phase $I I)$. The building was probably destroyed by fire, and the ruins were gradually covered by Layer 5 of dark brown soil and overlaying forest humus (Layer 6) after the settlement was abandoned.

There is little support for the dating of the first settlement phase, since small shards of poor quality and very fragile pottery predominate among the finds. The piece of iron (Pl. 1:2) found in the earliest cultural Layer 2 suggests that the hill was not inhabited before the Iron Age. This is also supported by jars, dishes with an inturned rim, baking lids (Pl. 1: 4-10,12), which are a common 
inventory of Iron Age houses. The reoxidation-fired handle ( $P l .1: 7)$ is perhaps better chronologically determinable, and point to the Late Hallstatt period, since such a firing process in pottery kilns with a reducing atmosphere and final oxidation was spreading over the Dolenjska region at that time. The handle was probably placed horizontally on the vessel, as the upright handles of the Hallstatt period pottery are usually wider and banded. This handle, however, has a round cross-section. Vessels with horizontal handles can be found in grave contexts from Dolenjske Toplice in the Krka river valley, dated to the Certosa and Negova phases. The Late Hallstatt decorative element is also visible on a pottery fragment with a knob with an impression in the centre (Pl. 1:3).

The second settlement or construction phase may also be dated to the Late Hallstatt period, based on the decoration of the applied wavy cordon on the fragments of the bowl with a handle ( $P l .2$ : 3 ). The motif of the wavy cordon often appears on the pottery from Dolenjske Toplice, among the grave goods from the Certosa and Negova phases. There are also comparisons for a handle with a pair of knobs on top and at the joint, just like the bowl from Vinji hrib. A fragment of a bobbin (Pl. 2:5) from Layer 4 on Vinji hrib is also worth mentioning, as it is most similar to finds from settlement contexts in Gradec near Blečji vrh and in Dolenjske Toplice, which are dated to the Certosa and Negova phases.

Among the finds from Layer 5 on Vinji hrib, which were deposited after the abandonment of the settlement, we can assign a pottery shard with a black-painted band (Pl. 2:17) to the Late Hallstatt period, while the rim and base modelled on a potter's wheel (Pl. 2: 14,15), can be assigned to a Late Medieval jar.

According to these indications, Vinji hrib above Vino was inhabited in the Late Hallstatt period, probably in the Certosa phase, and was abandoned at the end of the Early Iron Age. Similarities can be seen with the settlement at Gradec near Blečji vrh in the Posavje hills, where two construction phases in the Certosa phase were also identified, except that Gradec near Blečji vrh was first settled in the Copper Age, while the last settlement phase is dated to the Late Iron Age. Two stratigraphically separated building debris from the Certosa and Negova phases were also documented at Cvinger in Dolenjske Toplice, which was first settled in the Late Bronze Age and abandoned at the end of the Early Iron Age.

\section{Gradišče on Sloka gora}

The toponym Gradišče refers to a narrow, elongated mountain ridge that rises gently north of the present settlement Sloka Gora and reaches its highest altitude at $633.5 \mathrm{~m}$ asl. Below the peak there is a separating rampart in the southern part (Figs. 6; 7), which is also visible on the northern part of the ridge, while the settlement perimeter on the eastern and western slopes is less pronounced. Its interior has been partially transformed into several smaller terraces, which are supposedly a consequence of recent cultivation, while the ramparts are prehistoric. The estimated area of the settlement is about $1.84 \mathrm{ha}$. On the north-western slope, the LiDAR image also shows a bank, which is probably the edge of a former field. A possible cemetery in the immediate vicinity of the settlement has not yet been identified.

With a trench at the northern edge of the settlement (Figs. 7-9) two phases of settlement or construction were identified. The remains of the first are the cultural layers 2 and 3 of dark brown and yellow loam (Phase I), which lay directly on the natural deposits. We have not found any structural remains or traces of a defensive rampart or a wall, so we conclude that the settlement was not fortified at that time. The second settlement period (Phase II) is shown by the levelling of the terrain and thus the formation of a new floor, i.e. gravel surface (Layer 4 ). At the edge of the settlement a defensive wall was supposedly erected on top of the new floor surface, which collapsed in the course of time (Layer 5). It is possible that a wooden post construction was erected next to it, which is indicated by a hole dug through the gravel into the subsoil and two hollows in the bedrock. The brown loam (Layer 6), which spread behind the remains of the wall into the interior of the trench and contained most of the finds, is interpreted as debris of the second settlement phase. The overlying brown soil (Layer 7) accumulated over time after the abandonment of the settlement.

With the exception of the ceramic rings ( $P l$. 3: 1,3), which were present in almost all houses of the Hallstatt period, there are no more datable elements of the first settlement phase. The chronological determination of the second phase is based on a fragment of a ceramic strainer and a broken handle of the baking lid with knobs at the joint (Pl. 3: 4,7) found in the gravel floor surface (Layer 4 ) as well as a portable oven with applied wavy cordon decoration ( $P l .3: 10,13 ; 4: 3$ ) from 
the Layer 6 . These finds have the best analogies in settlement contexts of the Late Hallstatt period in the Dolenjska and Bela Krajina regions. The applied wavy cordon as a characteristic decorative element on the pottery of the Certosa and Negova phases, as well as the bobbins have already been discussed in connection with the dating of finds of the second settlement phase on Vinji hrib above Vino. Due to their common features (comparable size of the settlement and remains of everyday life) we assume that the life cycle of the hillfort on Sloka gora was the same as on Vinji hrib.

\section{Conclusion}

Trial trenches at Vinji hrib above Vino and Gradišče on Sloka gora confirmed the assumption that, despite their small size and modest finds, they were inhabited in prehistoric times. They belong to the group of hilltop settlements with an area of less than 2 ha, which were established in the Late Hallstatt period on the northern and northwestern edge of the territory of the Dolenjska Hallstatt Group. The cemeteries of some of them have not yet been discovered, nor are the tumuli visible in their immediate vicinity. It is possible that the graves were flat, and are therefore not visible in the terrain configuration. Such cases are known in the Posavje hills, which date to the time span of the settlements on Vinji hrib and Sloka gora. It is not so unusual that there are no tumuli around these settlements, and this could be an additional argument for the proposed chronological determination.
According to the present state of research, at least twenty new settlements were established in the western parts of the Dolenjska and Zasavje regions in the Late Hallstatt period, which has changed the settlement pattern compared to the previous period. The newly established settlements are usually smaller and have scarce fertile soil in the surroundings; however, they are located near ore deposits. The exploitation of metal ore minerals may have been one of the economic motives and livelihoods of its inhabitants. But other strategic reasons could also have influenced the settlement, which shows the spatial distribution of finds of the Negova helmets. They occur even in smaller settlements, which indicates a redistribution of military power and also a reinforced military protection of the boundaries of the Dolenjska Hallstatt community at the end of the Early Iron Age.

Translation: Nives Kokeza

Slikovno gradivo: Sl. 4, 5, 8, 9 (računalniška grafika: Drago Valoh, ZRC SAZU); t. 1-4 (risbe: Tamara Korošec, ZRC SAZU). Illustrations: Figs. 4, 5, 8, 9 (computer graphic: Drago Valoh, ZRC SAZU); Pls. 1-4 (drawings: Tamara Korošec, ZRC SAZU).

Članek je nastal v okviru raziskovalnega programa Arheološke raziskave (P6-0064), ki ga je sofinancirala Javna agencija za raziskovalno dejavnost Republike Slovenije iz državnega proračuna.

The authors acknowledge the financial support from the Slovenian Research Agency (research core funding No. P6-0064) 

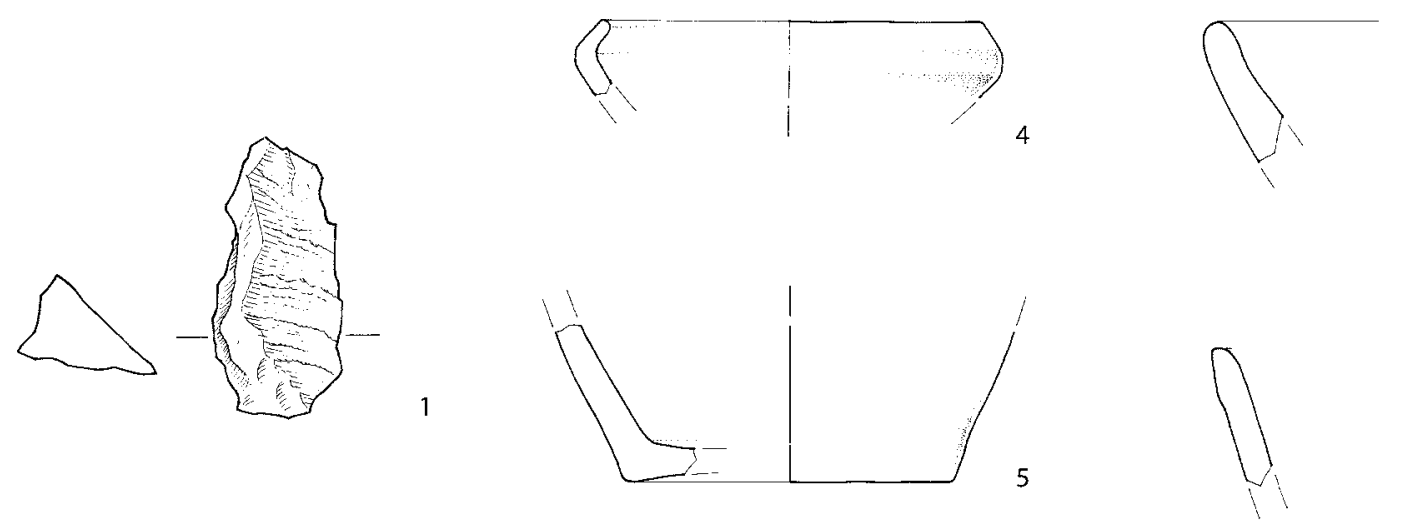

9
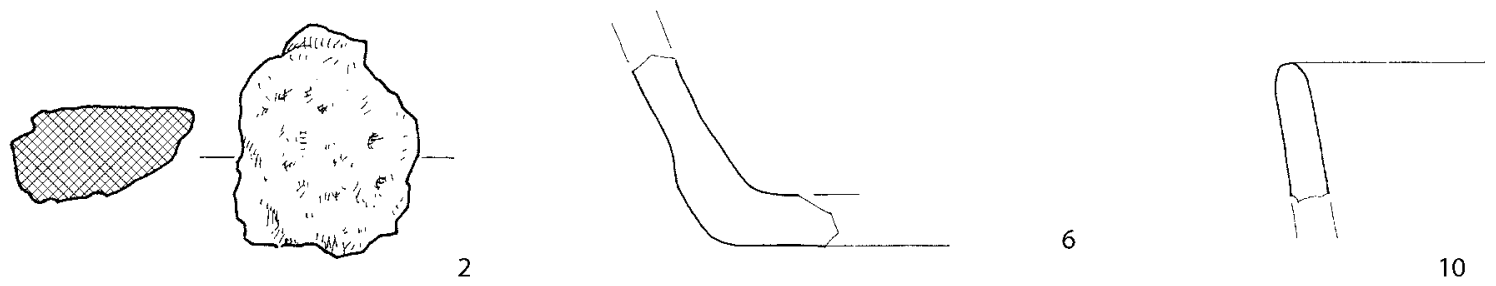

6
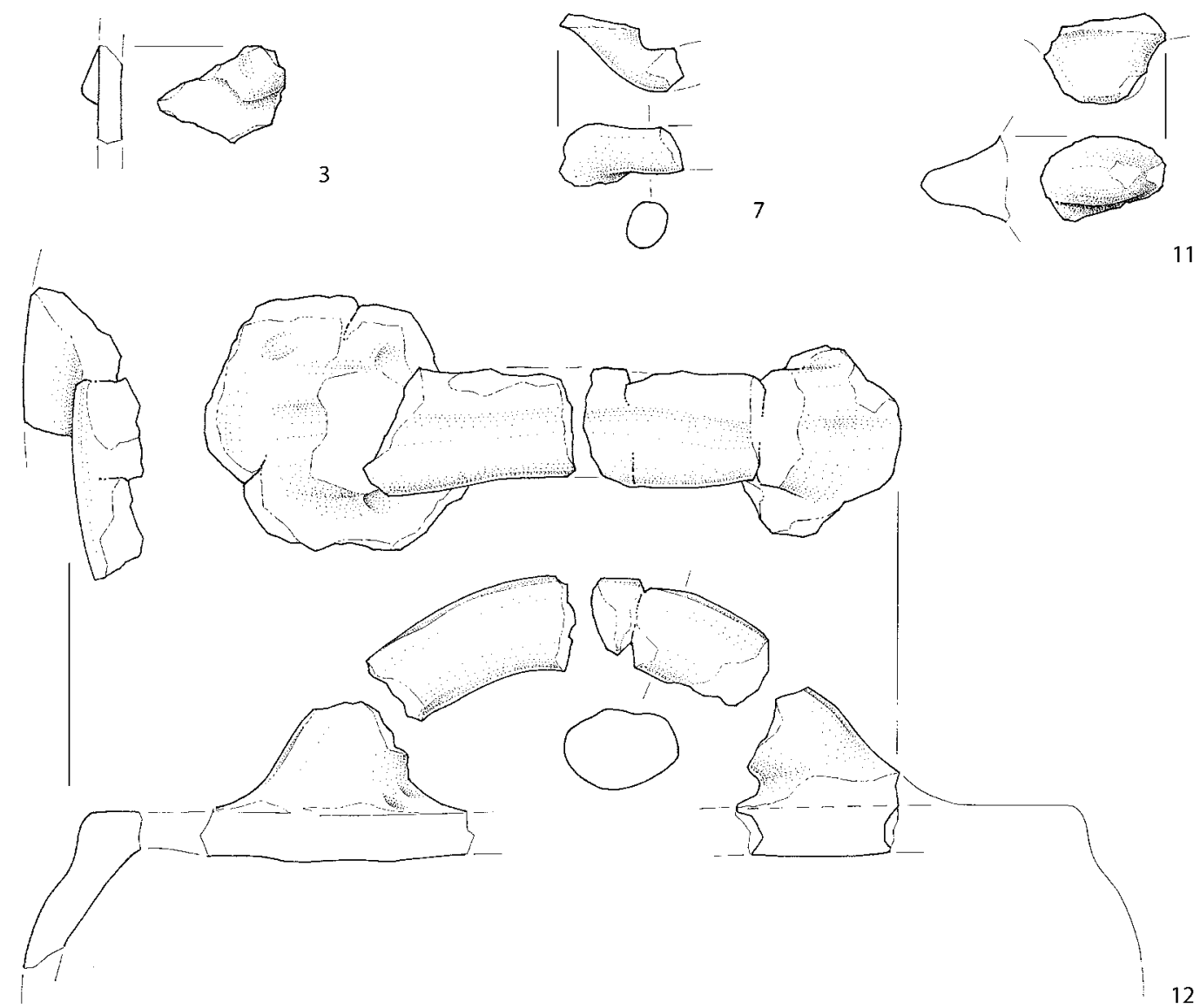

11

T. 1: Vinji hrib nad Vinom, sonda 1/1999. 1-12 iz plasti 1 (faza I). 1 kamen; 2 železo; ostalo keramika. M. 1,2 = 1:2; ostalo $=1: 3$.

Pl. 1: Vinji hrib above Vino, Trench 1/1999. 1-12 from Layer 1 (Phase I). 1 stone; 2 iron; rest pottery. Scale 1,2 = 1:2; other $=1: 3$. 

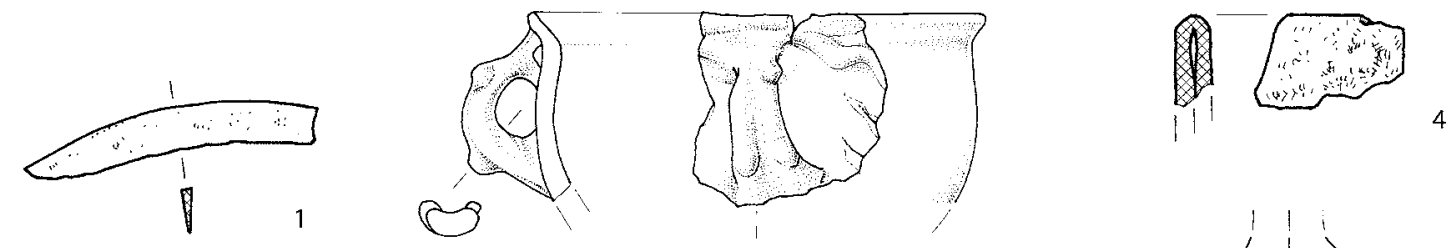

$3 a$
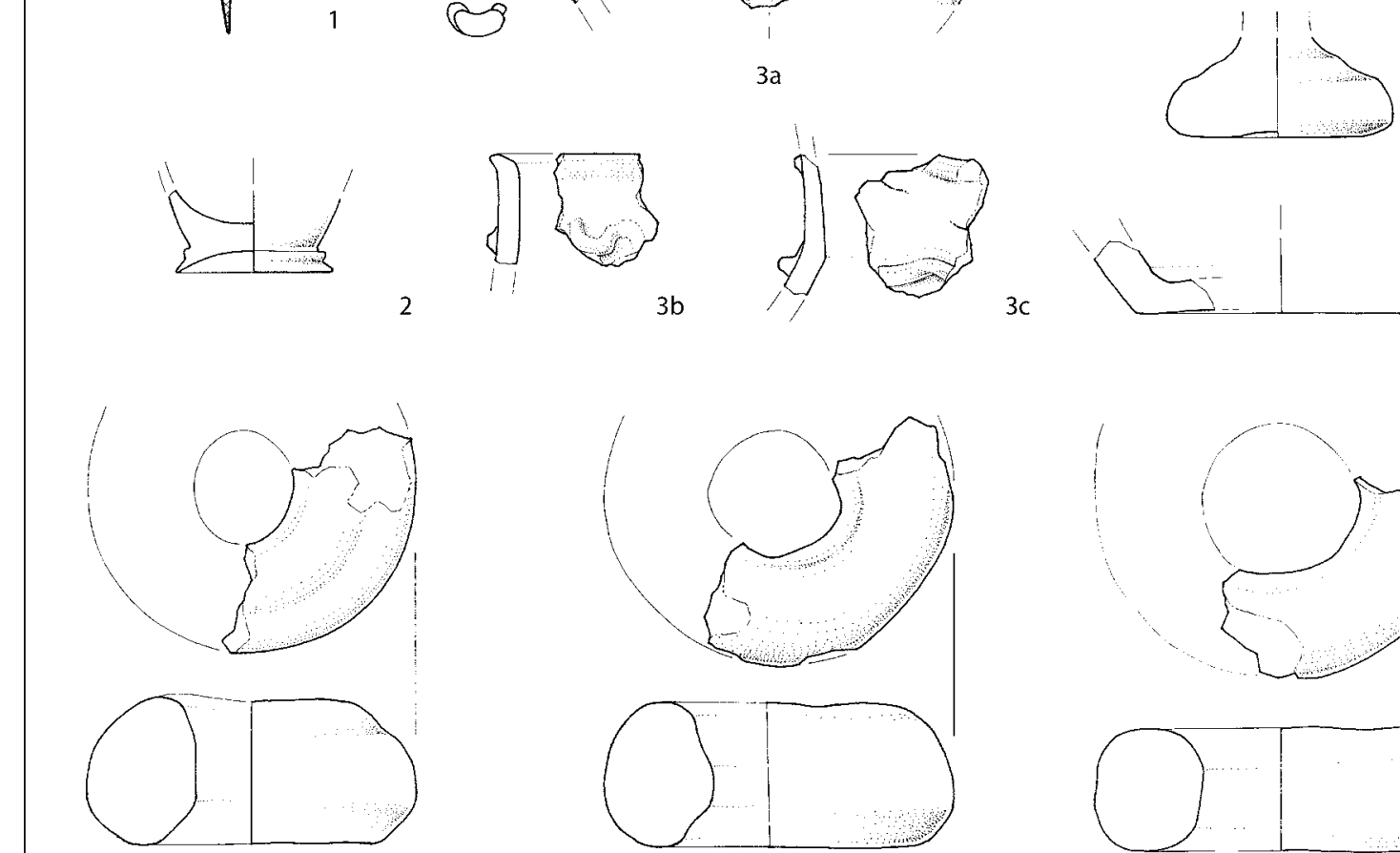

$3 b$

$3 c$

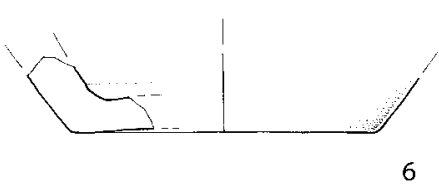

6

7
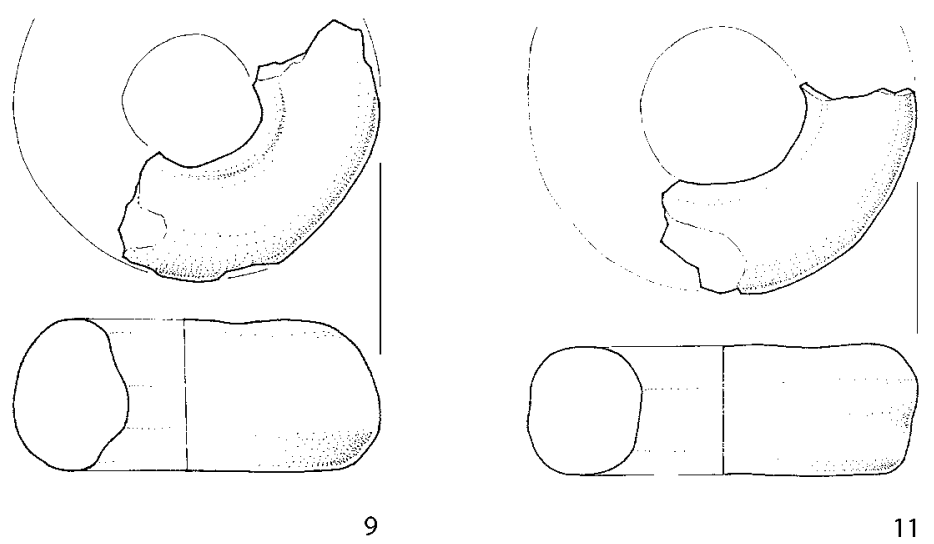

9
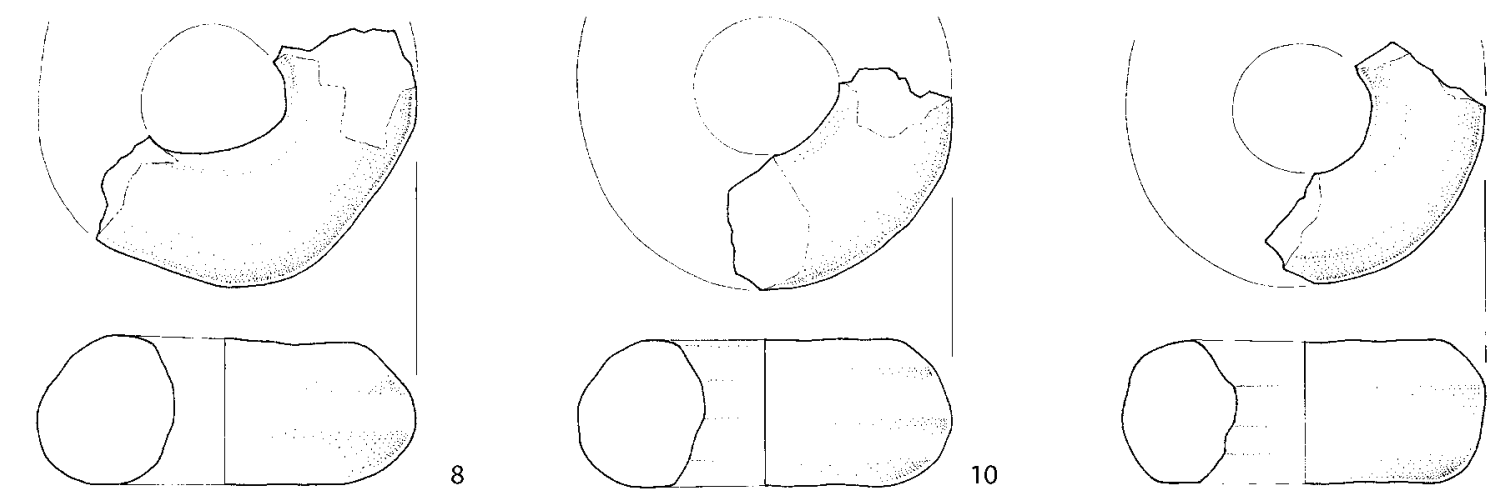

12
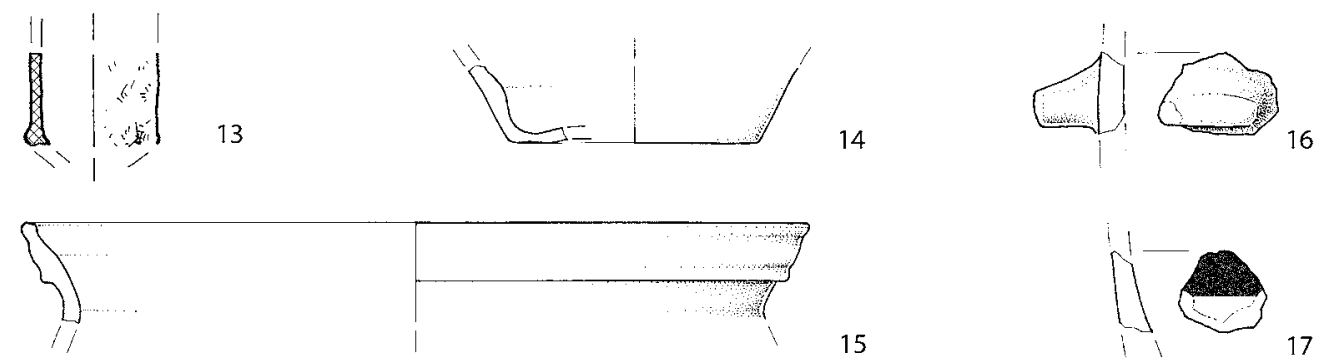

15

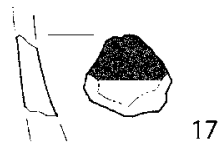

T. 2: Vinji hrib nad Vinom, sonda 1/1999. 1-12 iz plasti 4 (faza II); 13-17 iz plasti 5. 1,4,13 železo; ostalo keramika. M. $1,4,13=1: 2 ;$ ostalo $=1: 3$.

Pl. 2: Vinji hrib above Vino, Trench 1/1999. 1-12 from Layer 4 (Phase II); 13-17 from Layer 5. 1,4,13 iron; rest pottery. Scale $1,4,13=1: 2$; other $=1: 3$. 

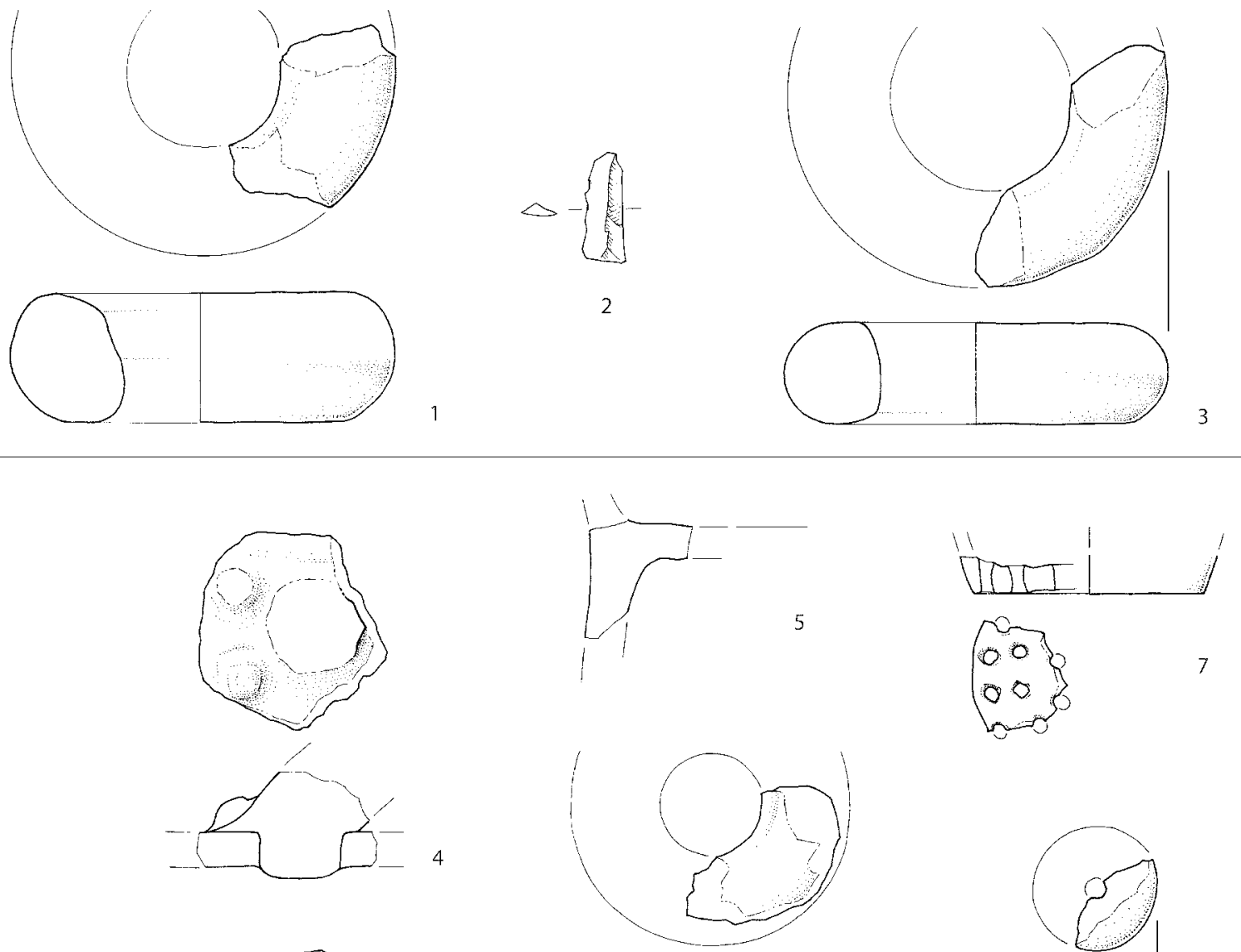

6

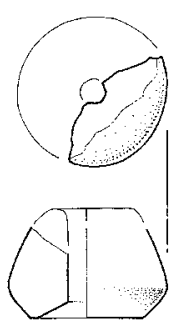

8
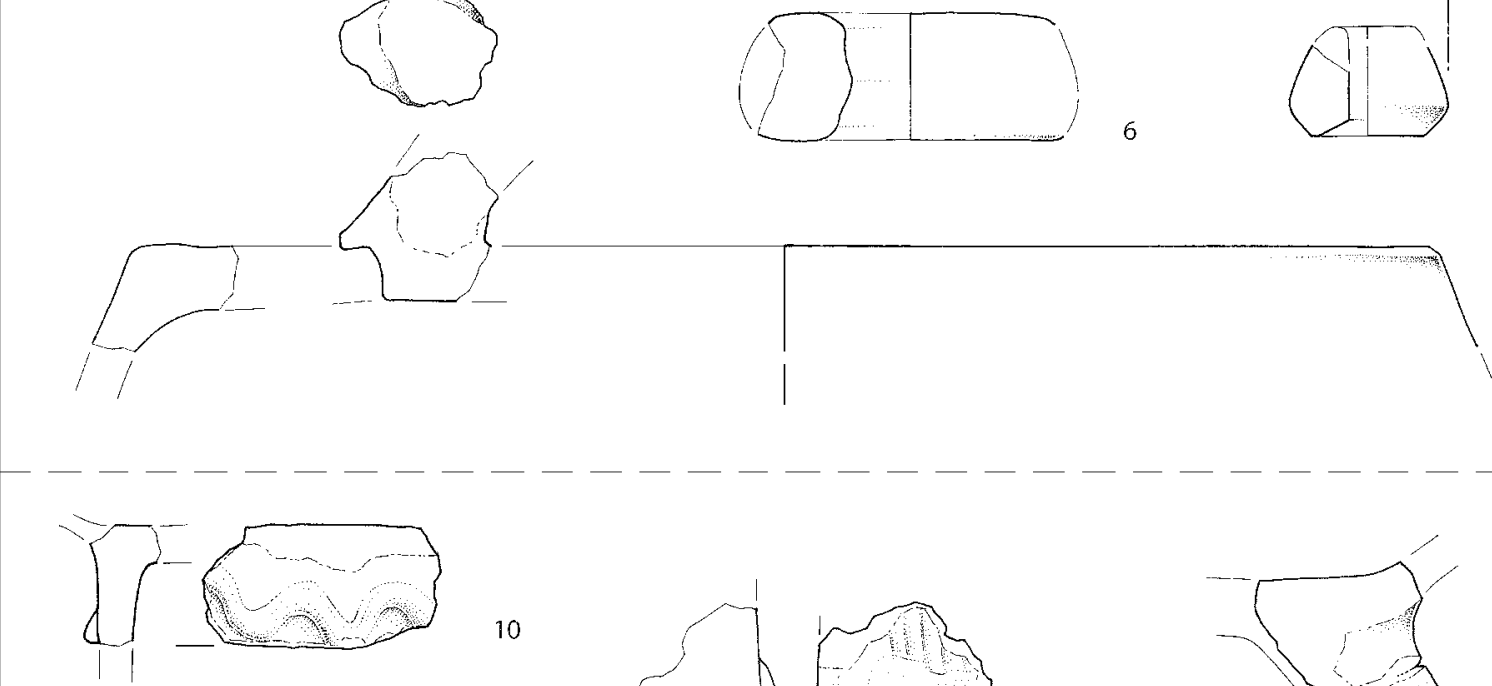

10
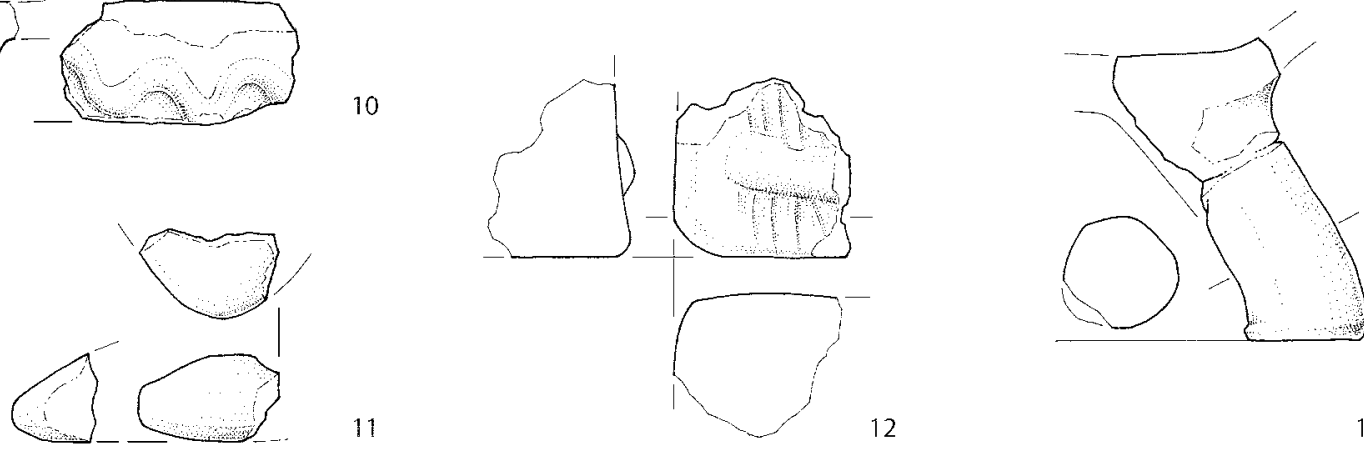

13

T. 3: Gradišče na Sloki gori, sonda 1/1999. 1-3 iz plasti 2 (faza I); 4-9 iz plasti 4 (tlak); 10-13 iz plasti 6 (faza II). 1 kamen; ostalo keramika. M. $1=1: 1 ;$ ostalo $=1: 3$.

Pl. 3: Gradišče at Sloka gora, Trench 1/1999. 1-3 from Layer 2 (Phase I); 4-9 from Layer 4 (pavement); 10-13 from Layer 6 (Phase II). 1 stone; rest pottery. Scale $1=1: 1$; other $=1: 3$. 

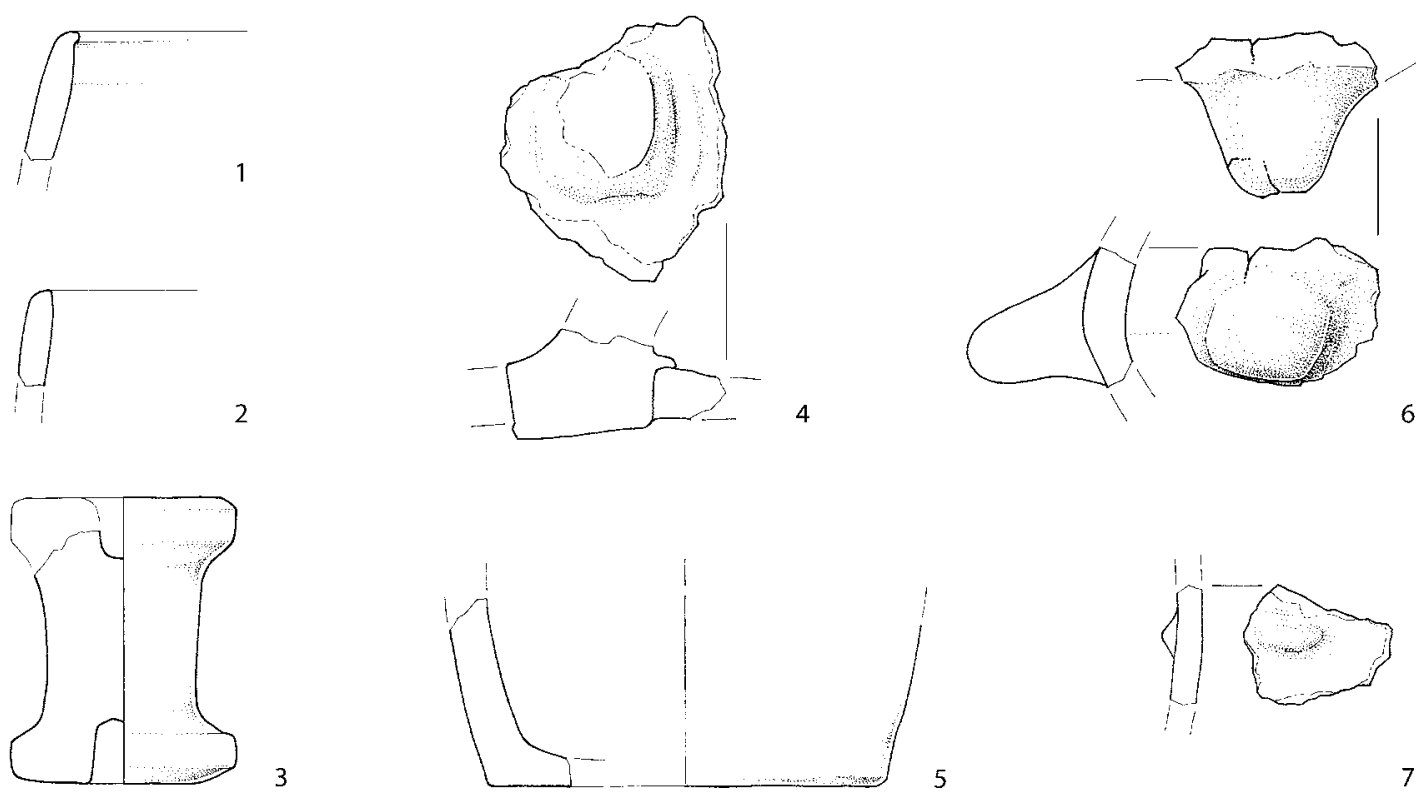

7
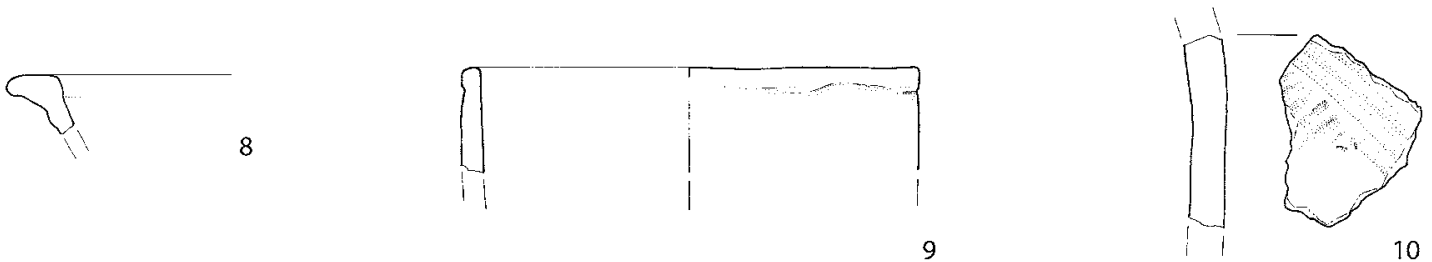

T. 4: Gradišče na Sloki gori, sonda 1/1999. 1-7 iz plasti 6 (faza II); 8-10 iz plasti 7. Vse keramika. M. = 1:3.

Pl. 4: Gradišče at Sloka gora, Trench 1/1999. 1-7 from Layer 6 (Phase II); 8-10 from Layer 7. All pottery. Scale = 1:3. 